\title{
33. INTERSTITIAL WATER STUDIES, LEG 31
}

\author{
Stan M. White, California State University at Fresno, Fresno, California
}

\section{INTRODUCTION}

During Leg 31, the Glomar Challenger cruise in the West Philippine Sea and Sea of Japan (Figure 1), a sampling program of interstitial waters and their connate sediments was carried out. This sampling program is a standard procedure on all DSDP legs.

This paper reports a study on the interstitial water chemistry of Sites 292, 293,296, 297, 299, and 302 (Figure 1). All data are presented in Tables 1-6 and in Figures 2-29. These sites, as well as others, reported a variety of sedimentary sequences and lithologies. Further site data and detailed lithologic descriptions are given in the appropriate site report chapters (Chapters 4, 5, $7,8,10$, and 13, this volume). Appendix A in these site report chapters contains detailed grain size, X-ray, and carbon carbonate data, as reported for the various lithologic units. A complete listing of the X-ray data is found in Cook et al. (Part V, Appendix I, this volume).

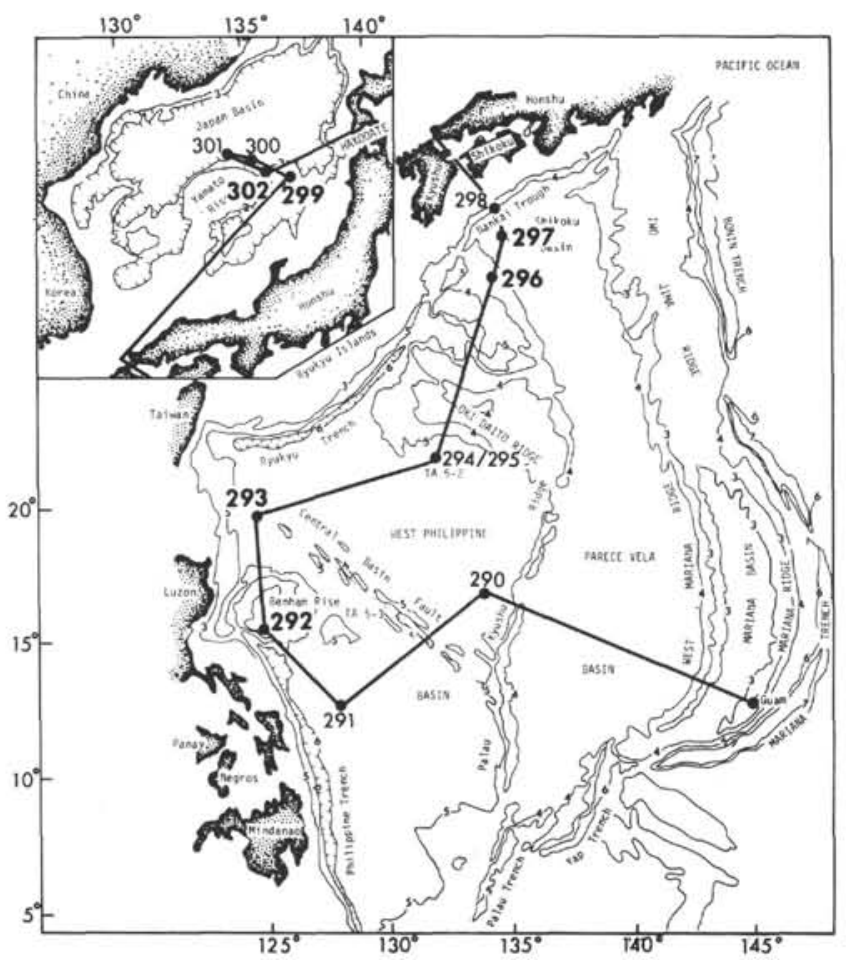

Figure 1. Location of drill sites, DSDP Leg 31. Sites discussed in this report are in boldface. From map: Topography of North Pacific, T. E. Chase, H. W. Menard, and J. Mammerickx, 1971. Scale 1:6,500,000; contour depths in kilometers.

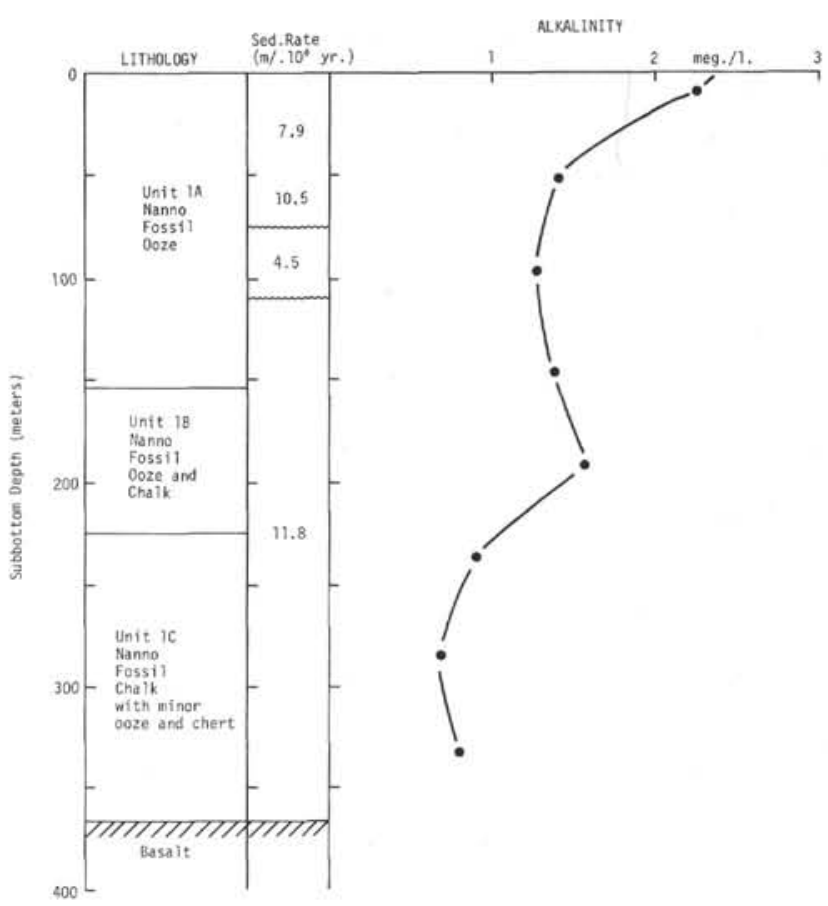

Figure 2. Site 292 - alkalinity.

\section{Direction of the Study}

Time and background prevented a detailed analysis of the interstitial water chemistry of each site. This report will attempt to briefly characterize the chemical changes, if present, in the interstitial waters, with conclusions drawn on diagenetic or other sediment processes affecting this chemistry. For the results presented herein, extensive reference has been made to previous papers on interstitial water studies by Gieskes $(1973,1974)$.

\section{GEOCHEMICAL SAMPLING PROCEDURE}

On shipboard, 6-10 cm length of core (approximately $200-340 \mathrm{cc}$ ) is taken at approximately 50 -meter intervals of subdepth. As soon as this sample reaches room temperature, it is squeezed to yield $20-30 \mathrm{ml}$ of interstitial water. Except for a 2-3 ml volume used in shipboard analyses, this water is packaged in two aliquots (one in a fused glass ampoule, and one in a fused polyvinyl tube), and stored at $4^{\circ} \mathrm{C}$.

\section{ANALYSIS METHODS}

\section{pH, Alkalinity, and Salinity}

The methods used to determine $p \mathrm{H}$, alkalinity, and salinity are those used in past DSDP legs and are described in Chapter 1 (this volume). The values of these 
TABLE 1

Site $292\left(15^{\circ} 49.11^{\prime} \mathrm{N}, 124^{\circ} 39.05^{\prime} \mathrm{E} ; 2943 \mathrm{~m}\right)$

\begin{tabular}{|c|c|c|c|c|c|c|c|c|c|c|c|c|c|}
\hline $\begin{array}{l}\text { Sample } \\
\text { (Core, } \\
\text { Section) }\end{array}$ & $\begin{array}{l}\text { Subbottom } \\
\text { Depth } \\
\text { (m) }\end{array}$ & $p \mathrm{H}^{\mathrm{a}}$ & $p \mathrm{H}^{\mathrm{b}}$ & $\mathrm{Alk}^{\mathrm{C}}$ & $\mathrm{Sal}^{\mathrm{d}}$ & $\mathrm{Cl}^{\mathrm{e}}$ & $\mathrm{Ca}^{++\mathrm{f}}$ & $\mathrm{Mg}^{++f}$ & $\mathrm{SO}_{4}=\mathrm{f}$ & $\mathrm{K}^{+\mathrm{g}}$ & $\mathrm{Sr}^{++\mathrm{g}}$ & $\mathrm{Mn}^{++\mathrm{g}}$ & $\mathrm{Si}^{\mathrm{h}}$ \\
\hline $2-2$ & 9.5 & 7.4 & 7.3 & 2.2 & 35.2 & 19.6 & 11.0 & 51.7 & $(36.1)^{\mathrm{i}}$ & 413 & 17.5 & 4.1 & \\
\hline $6-6$ & 52.0 & 7.5 & 7.4 & 1.4 & 35.2 & 18.3 & 15.4 & 49.3 & 29.6 & 383 & 30.0 & $\begin{array}{c}0.4 \\
(<0.5)\end{array}$ & 128 \\
\hline $11-5$ & 99.5 & 7.6 & 7.5 & 1.3 & 35.2 & 19.5 & 25.5 & 34.8 & 26.7 & 382 & 34.4 & 2.0 & 247 \\
\hline $16-5$ & 147.0 & 7.3 & 7.4 & 1.4 & 35.2 & 19.3 & 32.2 & 29.5 & 26.9 & 376 & 38.1 & 0.7 & 661 \\
\hline $21-4$ & 193.0 & 7.1 & 7.3 & 1.6 & 35.5 & 19.2 & 31.8 & 35.2 & 29.3 & 389 & 57.5 & 1.3 & \\
\hline $26-1$ & 236.0 & & 7.3 & 0.9 & 36.8 & 20.1 & 41.2 & 30.0 & 27.6 & 321 & 42.4 & $\begin{array}{c}0.3 \\
(<0.5)\end{array}$ & 1094 \\
\hline $31-1$ & 283.5 & & 7.4 & 0.7 & 36.8 & 20.1 & 47.4 & 27.1 & 28.6 & 316 & 41.8 & $\begin{array}{c}0.4 \\
(<0.5)\end{array}$ & 1115 \\
\hline $36-3$ & 334.0 & & 7.3 & 0.8 & 37.7 & 23.4 & 67.0 & 17.6 & 28.8 & 278 & 35.7 & $\begin{array}{c}0.3 \\
(<0.5)\end{array}$ & \\
\hline
\end{tabular}

\begin{tabular}{|c|c|}
\hline 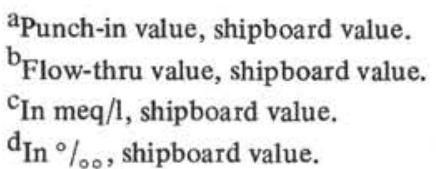 & $\begin{array}{l}\mathrm{e}_{\text {In }} \% \text {. } \\
\mathrm{f}_{\text {In m mole/l. }} . \\
\mathrm{g}_{\text {In ppm. }} . \\
\mathrm{h}_{\text {In } \mu \text {-at. }}\end{array}$ \\
\hline
\end{tabular}

TABLE 2

Site $293\left(20^{\circ} 21.25^{\prime} \mathrm{N}, 124^{\circ} 05.65^{\prime} \mathrm{E} ; 5599 \mathrm{~m}\right)$

\begin{tabular}{|c|c|c|c|c|c|c|c|c|c|c|c|c|c|}
\hline $\begin{array}{l}\text { Sample } \\
\text { (Core, } \\
\text { Section) }\end{array}$ & $\begin{array}{l}\text { Subbottom } \\
\text { Depth } \\
\text { (m) }\end{array}$ & $p \mathrm{H}^{\mathrm{a}}$ & $p \mathrm{H}^{\mathrm{b}}$ & $\mathrm{Alk}^{\mathrm{C}}$ & $\mathrm{Sal}^{\mathrm{d}}$ & $\mathrm{Cl}^{\mathrm{e}}$ & $\mathrm{Ca}^{++\mathrm{f}}$ & $\mathrm{Mg}^{++\mathrm{f}}$ & $\mathrm{SO}_{4}=\mathrm{f}$ & $\mathrm{K}^{+\mathrm{g}}$ & $\mathrm{Sr}^{++\mathrm{g}}$ & $\mathrm{Mn}^{++\mathrm{g}}$ & $\mathrm{Si}^{\mathrm{h}}$ \\
\hline $2-4$ & 94.5 & 7.5 & 7.8 & 29.2 & 34.1 & 18.7 & 9.7 & 39.5 & 6.8 & 447 & 8.7 & 0.6 & 530 \\
\hline 4-1 & 147.0 & 7.5 & 7.8 & 24.6 & 33.0 & 19.8 & 6.2 & 41.0 & 5.7 & 441 & 7.6 & $\begin{array}{c}0.4 \\
(<0.5)\end{array}$ & 506 \\
\hline $7-2$ & 215.0 & 7.4 & 8.0 & 14.1 & 33.3 & 19.8 & 11.5 & 41.5 & 9.2 & 386 & 6.6 & $\begin{array}{c}0.0 \\
(<0.5)\end{array}$ & 403 \\
\hline $8-1$ & 261.0 & & 7.9 & 13.3 & 32.4 & 19.4 & 9.4 & 43.6 & 3.0 & 369 & 8.5 & 0.7 & 259 \\
\hline $10-2$ & 301.0 & 7.7 & 8.0 & 7.7 & 33.0 & 19.9 & 12.2 & 40.0 & 8.8 & 310 & 7.3 & $\begin{array}{c}0.3 \\
(<0.5)\end{array}$ & 274 \\
\hline $12-0$ & 354.5 & & 8.2 & 4.7 & 31.9 & 19.7 & 17.8 & 26.9 & 18.1 & 317 & 9.2 & 0.7 & 150 \\
\hline $13-1$ & 384.5 & 7.6 & 8.2 & 2.7 & 33.0 & 19.1 & 19.7 & 27.2 & 11.9 & 300 & 10.7 & 1.3 & 150 \\
\hline $15-3$ & 444.5 & & 8.3 & 1.7 & 31.9 & 19.9 & 28.7 & 19.9 & 5.2 & 189 & 10.7 & 0.9 & 131 \\
\hline
\end{tabular}

\begin{tabular}{|c|c|}
\hline $\begin{array}{l}{ }^{a} \text { Punch-in value, shipboard value. } \\
\text { b} \text { Flow-thru value, shipboard value. }\end{array}$ & $\begin{array}{l}\mathrm{e}_{\text {In }} \% \text {. } \\
\mathrm{f}_{\text {In m mole } / 1}\end{array}$ \\
\hline${ }^{{ }^{c} \text { In meq } / 1, \text { shipboard value. }}$ & $\mathrm{g}_{\text {In ppm. }}$ \\
\hline
\end{tabular}

parameters, for the sites studied here, are shown in Tables 1-6. The values are all shipboard values, and the $p \mathrm{H}$ data have not been corrected to in situ values.

Methods used to determine amounts of the major and minor chemical elements are discussed briefly for each element.

\section{Calcium}

Complexometric titration with EGTA (Tsunogai et al., 1968) as modified by Gieskes (1973) was used. Copenhagen IAPSO standard seawater was used as the standard. Corrections for strontium were made using the experimental $\mathrm{Sr}$ values.

\section{Magnesium}

The values of magnesium were obtained from EDTA titrations $(\mathrm{Ca}+\mathrm{Sr}+\mathrm{Mg})$ and subtraction of $(\mathrm{Ca}+\mathrm{Sr})$ from these titrations. $n$-butanol was used as an extractant. IAPSO standard seawater was used for the standardization of the EDTA solution using the new $\mathrm{Mg} / \mathrm{Cl}$ ratio of Carpenter and Manella (1973).

\section{Dissolved Silica}

An appropriate version of the method of Strickland and Parsons (1968) was used. The lack of values for certain samples (Tables 1-6) is due to the insufficient amount of remaining sample following the other analyses.

\section{Chloride}

Chlorinity was determined on samples using a Mohr titration with $\mathrm{AgNO}_{3}$ and $\mathrm{K}_{2} \mathrm{CrO}_{4}$ as indicator. The analyses were very irreproducible, with an estimated precision of $\pm 3 \%$. Observed variations with depth (Tables 1-6) are probably not real. 
TABLE 3

Site $296\left(29^{\circ} 20.41^{\prime} \mathrm{N}, 133^{\circ} 31.52^{\prime} \mathrm{E} ; 2920 \mathrm{~m}\right)$

\begin{tabular}{|c|c|c|c|c|c|c|c|c|c|c|c|c|c|}
\hline $\begin{array}{l}\text { Sample } \\
\text { (Core, } \\
\text { Section) }\end{array}$ & $\begin{array}{l}\text { Subbottom } \\
\text { Depth } \\
\text { (m) }\end{array}$ & $p \mathrm{H}^{\mathrm{a}}$ & $p \mathrm{H}^{\mathrm{b}}$ & $\mathrm{Alk}^{\mathrm{c}}$ & $\mathrm{Sal}^{\mathrm{d}}$ & $\mathrm{Cl}^{\mathrm{e}}$ & $\mathrm{Ca}^{++\mathrm{f}}$ & $\mathrm{Mg}^{++\mathrm{f}}$ & $\mathrm{SO}_{4}=\mathrm{f}$ & $\mathrm{K}^{+\mathrm{g}}$ & $\mathrm{Sr}^{++\mathrm{g}}$ & $\mathrm{Mn}^{++\mathrm{g}}$ & $\mathrm{Si}^{\mathrm{h}}$ \\
\hline $1-3$ & 4.5 & 7.3 & 7.6 & 3.2 & 34.9 & 19.4 & 10.1 & 51.0 & 28.8 & 433 & 9.3 & 9.0 & 642 \\
\hline $2-5$ & 14.0 & 7.3 & 7.4 & 3.3 & 34.9 & 19.5 & 9.7 & 51.9 & 26.9 & 445 & 4.7 & 7.2 & 614 \\
\hline $5-3$ & 39.5 & 7.3 & 7.5 & 2.9 & 35.2 & 19.8 & 9.9 & 48.1 & 26.5 & 382 & 6.0 & 3.7 & \\
\hline $10-5$ & 90.0 & 7.2 & 7.6 & 2.3 & 34.4 & 19.5 & 10.0 & 48.2 & 25.2 & 412 & 16.2 & 1.9 & \\
\hline $15-3$ & 134.5 & 7.1 & 7.4 & 3.0 & 34.4 & 19.5 & 12.5 & 45.1 & 24.8 & 401 & 21.2 & 1.1 & 755 \\
\hline $20-3$ & 182.0 & 7.3 & 7.3 & 2.7 & 34.6 & 19.5 & 14.3 & 49.3 & 25.9 & 365 & 21.2 & 1.6 & 662 \\
\hline $25-3$ & 229.5 & 7.0 & 7.2 & 2.8 & 35.2 & 19.6 & 19.8 & 38.9 & 23.6 & 397 & 26.3 & 3.7 & 987 \\
\hline $30-4$ & 278.5 & & 7.3 & 2.0 & 35.2 & 19.6 & 23.7 & 36.8 & 25.0 & 428 & 16.2 & & 1068 \\
\hline $35-5$ & 327.5 & & 7.4 & 1.4 & 36.6 & 19.9 & 28.7 & 38.8 & 26.1 & 380 & 28.1 & 0.6 & \\
\hline $40-1$ & 369.0 & & 8.4 & 0.6 & 36.3 & 19.3 & 33.6 & 27.4 & 27.8 & 431 & 11.3 & 0.6 & \\
\hline $45-2$ & 418.0 & & 8.4 & 0.8 & 38.2 & 20.1 & 36.7 & 26.2 & $(32.1)^{\mathrm{i}}$ & 467 & 10.0 & 0.6 & \\
\hline
\end{tabular}

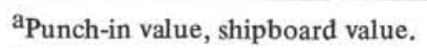

${ }^{\mathrm{b}}$ Flow-thru value, shipboard value.

$\mathrm{e}_{\mathrm{In}} \%$.

${ }^{\mathrm{i}}$ Doubtful value

${ }^{\mathrm{c}}$ In meq/1, shipboard value.

${ }^{\mathrm{f}}$ In $\mathrm{m}$ mole/l.

$\mathrm{d}_{\text {In } \%} \%$, shipboard value.

g In ppm.

$\mathrm{h}_{\text {In } \mu \mathrm{g}-\mathrm{at}}$.

TABLE 4

Site $297\left(30^{\circ} 52.36^{\prime} \mathrm{N}, 134^{\circ} 09.89^{\prime} \mathrm{E} ; 4458 \mathrm{~m}\right)$

\begin{tabular}{|c|c|c|c|c|c|c|c|c|c|c|c|c|c|}
\hline $\begin{array}{l}\text { Sample } \\
\text { (Core, } \\
\text { Section) }\end{array}$ & $\begin{array}{l}\text { Subbottom } \\
\text { Depth } \\
\text { (m) }\end{array}$ & $p \mathrm{H}^{\mathrm{a}}$ & $p \mathrm{H}^{\mathrm{b}}$ & $\mathrm{Alk}^{\mathrm{c}}$ & $\mathrm{Sal}^{\mathrm{d}}$ & $\mathrm{Cl}^{\mathrm{e}}$ & $\mathrm{Ca}^{++\mathrm{f}}$ & $\mathrm{Mg}^{++\mathrm{f}}$ & $\mathrm{SO}_{4}=\mathrm{f}$ & $\mathrm{K}^{+\mathrm{g}}$ & $\mathrm{Sr}^{++\mathrm{g}}$ & $\mathrm{Mn}^{++\mathrm{g}}$ & $\mathrm{Si}^{\mathrm{h}}$ \\
\hline $3-1$ & 21.5 & 7.6 & 7.7 & 17.8 & 34.4 & 19.2 & 8.0 & 47.5 & 16.4 & 427 & 7.2 & 5.1 & 855 \\
\hline $5-4$ & 64.0 & 7.3 & 7.6 & 21.4 & 33.8 & 19.9 & 4.1 & 42.6 & 7.2 & 392 & 7.7 & 0.8 & 903 \\
\hline $6-5$ & 84.5 & 7.7 & 8.1 & 23.2 & 33.6 & 19.8 & 5.4 & 40.7 & 5.9 & 418 & 6.9 & 0.9 & 723 \\
\hline $8-5$ & 113.0 & 7.3 & 7.8 & 23.1 & 33.3 & 19.6 & 5.6 & 39.8 & & 354 & 7.8 & 0.7 & 822 \\
\hline $10-5$ & 160.5 & 7.5 & 7.9 & 22.6 & 33.0 & 19.9 & 8.3 & 37.6 & 2.4 & 357 & 9.6 & 1.4 & 965 \\
\hline $11-3$ & 205.0 & 7.2 & 7.8 & 17.8 & 32.7 & 19.9 & 9.3 & 37.1 & 4.2 & 317 & 11.4 & 0.6 & 994 \\
\hline $12-2$ & 251.0 & 7.3 & 7.7 & 14.9 & 32.7 & 19.7 & 13.1 & 35.2 & 7.6 & 318 & 10.4 & 1.8 & \\
\hline $14-5$ & 322.0 & 7.6 & 8.2 & 5.5 & 31.9 & 19.4 & 11.9 & 27.1 & 7.1 & 292 & 12.7 & $\begin{array}{c}0.0 \\
(<0.5)\end{array}$ & \\
\hline $17-2$ & 393.5 & 7.7 & 7.9 & 6.9 & 32.2 & 19.9 & 11.2 & 23.9 & 2.9 & 271 & 15.0 & $\begin{array}{c}0.4 \\
(<0.5)\end{array}$ & 965 \\
\hline $18-1$ & 430.0 & 7.6 & 7.6 & 4.9 & 33.3 & 19.5 & 12.1 & 22.7 & & & & & \\
\hline $20-2$ & 507.5 & 7.2 & 7.4 & 6.3 & 32.2 & 19.9 & 16.1 & 19.3 & 7.5 & 239 & 16.3 & 0.9 & 526 \\
\hline $22-3$ & 536.5 & & 8.2 & 4.6 & 31.9 & 19.2 & 18.1 & 17.9 & 8.6 & 259 & 13.8 & $\begin{array}{c}0.0 \\
(<0.5)\end{array}$ & 270 \\
\hline $23-3$ & 594.5 & & 7.8 & 6.2 & 30.0 & 20.1 & 18.6 & 17.2 & 10.2 & & 17.2 & $\begin{array}{c}0.4 \\
(<0.5)\end{array}$ & 446 \\
\hline $24-1$ & 620.0 & & 8.3 & 5.1 & 33.0 & 20.2 & 20.1 & 13.7 & 7.0 & & 15.0 & $\begin{array}{c}0.3 \\
(<0.5) \\
\end{array}$ & \\
\hline $\begin{array}{l}{ }^{\text {aPunch-in }} \\
b_{\text {Flow-thr }} \\
{ }^{c} \text { In meq } / 1 \text {, } \\
d_{\text {In } \% \text {, s }}\end{array}$ & $\begin{array}{l}\text { alue, shipboar } \\
\text { value, shipbo } \\
\text { shipboard valu } \\
\text { ipboard value }\end{array}$ & $\begin{array}{l}\text { value } \\
\text { d valu }\end{array}$ & & & $\begin{array}{l}\mathrm{e}_{\text {In }} \% \\
\mathrm{f}_{\text {In } \mathrm{mm}} \\
\mathrm{g}_{\text {In } \mathrm{ppn}} \\
\mathrm{h}_{\text {In } \mu \mathrm{g}-}\end{array}$ & $e / 1$. & & & & & & & \\
\hline
\end{tabular}

\section{Sulfate}

The titration method of Cescon and Macchi (1973) was used. IAPSO standard seawater was used as a standard.

\section{Manganese}

One $\mathrm{ml}$ of samples was diluted with $4 \mathrm{ml}$ of distilled water, and $0.1 \mathrm{ml}$ of a $50,000 \mu \mathrm{g} / \mathrm{ml}$ Lanthanum (La) solution was added. Standards were made in La Jolla pier water (range 0-10 ppm $\mathrm{Mn}$ in undiluted samples). Analysis was done by means of atomic absorption (AA) spectrometry, using a Perkin-Elmer model 403 spectrometer. AA reproducibility is to $0.5 \mathrm{ppm}$. Values less than $0.5 \mathrm{ppm}$ are reported as $(<0.5) \mathrm{ppm}$ in Tables 1-6.

\section{Strontium}

Two $\mathrm{ml}$ of the manganese solution was further diluted with $8 \mathrm{ml}$ of a $5000 \mathrm{ppm}$ La solution. Analysis was 
TABLE 5

Site $299\left(39^{\circ} 29.69^{\prime} \mathrm{N}, 137^{\circ} 39.72^{\prime} \mathrm{E} ; 2599 \mathrm{~m}\right)$

\begin{tabular}{|c|c|c|c|c|c|c|c|c|c|c|c|c|c|}
\hline $\begin{array}{l}\text { Sample } \\
\text { (Core, } \\
\text { Section) }\end{array}$ & $\begin{array}{l}\text { Subbottom } \\
\text { Depth } \\
\text { (m) }\end{array}$ & $p \mathrm{H}^{\mathrm{a}}$ & $p \mathrm{H}^{\mathrm{b}}$ & $\mathrm{Alk}^{\mathrm{c}}$ & $\mathrm{Sal}^{\mathrm{d}}$ & $\mathrm{Cl}^{\mathrm{e}}$ & $\mathrm{Ca}^{++\mathrm{f}}$ & $\mathrm{Mg}^{++\mathrm{f}}$ & $\mathrm{SO}_{4}=\mathrm{f}$ & $\mathrm{K}^{+\mathrm{g}}$ & $\mathrm{Sr}^{++\mathrm{g}}$ & $\mathrm{Mn}^{++\mathrm{g}}$ & $\mathrm{Si}^{\mathrm{h}}$ \\
\hline $1-5$ & 7.5 & 7.6 & 8.3 & 10.2 & 33.3 & 19.4 & 9.08 & 46.8 & 22.3 & 401 & 6.8 & 4.3 & 464 \\
\hline $5-1$ & 39.5 & 7.5 & 7.5 & 22.3 & 32.2 & 19.2 & 4.8 & 44.8 & 7.0 & 398 & 7.3 & $\begin{array}{c}0.0 \\
(<0.5)\end{array}$ & 732 \\
\hline $10-4$ & 91.5 & 7.4 & 7.9 & 28.9 & 32.4 & 19.3 & 4.9 & 39.7 & 6.8 & 362 & 8.9 & $\begin{array}{c}0.5 \\
(<0.5)\end{array}$ & 734 \\
\hline $15-4$ & 139.0 & 7.2 & 7.5 & 20.1 & 33.0 & 19.4 & 6.0 & 44.0 & 9.1 & 327 & 6.1 & 0.8 & 830 \\
\hline $20-2$ & 183.5 & & 7.9 & 27.4 & 32.7 & 19.1 & 6.0 & 34.6 & 5.8 & 361 & 8.2 & $\begin{array}{c}0.1 \\
(<0.5)\end{array}$ & 680 \\
\hline $30-4$ & 329.0 & & 8.0 & 13.1 & 32.2 & 19.7 & 12.2 & 24.8 & 5.4 & 342 & 9.3 & $\begin{array}{c}0.4 \\
(<0.5)\end{array}$ & 813 \\
\hline $32-1$ & 400.5 & & 7.9 & 6.5 & 33.0 & 19.8 & 14.9 & 24.7 & 5.0 & 335 & 7.9 & 0.6 & 616 \\
\hline $36-2$ & 497.0 & & 8.0 & 2.5 & 31.9 & 20.1 & 27.8 & 23.0 & 2.5 & 268 & 5.6 & $\begin{array}{c}0.0 \\
(<0.5)\end{array}$ & \\
\hline
\end{tabular}

${ }^{\text {a}}$ Punch-in value, shipboard value.

$\mathrm{b}_{\text {Flow-thru value, shipboard value. }}$

$\mathrm{c}_{\text {In meq/ } / 1, \text { shipboard value. }}$

$\mathrm{d}_{\mathrm{In}} \%$, shipboard value.
$\mathrm{e}_{\mathrm{In}} \%$,

$\mathrm{f}_{\text {In mmole/1. }}$

g In ppm.

$\mathrm{h}_{\text {In } \mu \mathrm{g}-\mathrm{at} \text {. }}$

TABLE 6

Site $302\left(40^{\circ} 20.13^{\prime} \mathrm{N}, 136^{\circ} 54.01^{\prime} \mathrm{E} ; 2399 \mathrm{~m}\right)$

\begin{tabular}{rrrrrrrrrrrrrr}
\hline $\begin{array}{c}\text { Sample } \\
\begin{array}{c}\text { (Core, } \\
\text { Section) }\end{array}\end{array}$ & $\begin{array}{c}\text { Subbottom } \\
\text { Depth } \\
(\mathrm{m})\end{array}$ & $p \mathrm{H}^{\mathrm{a}}$ & $p \mathrm{H}^{\mathrm{b}}$ & $\mathrm{Alk}^{\mathrm{c}}$ & $\mathrm{Sal}^{\mathrm{d}}$ & $\mathrm{Cl}^{\mathrm{e}}$ & $\mathrm{Ca}^{++\mathrm{f}}$ & $\mathrm{Mg}^{++\mathrm{f}}$ & $\mathrm{SO}_{4}=$ & $\mathrm{K}^{+\mathrm{g}}$ & $\mathrm{Sr}^{++\mathrm{g}}$ & $\mathrm{Mn}^{++\mathrm{g}}$ & $\mathrm{Si}^{\mathrm{h}}$ \\
\hline $2-5$ & 26.5 & 7.2 & 7.3 & 12.9 & 33.3 & 19.0 & 9.7 & 46.8 & 20.3 & 402 & 7.8 & 4.3 & 963 \\
$5-4$ & 82.0 & 7.4 & 7.6 & 16.2 & 33.3 & 19.6 & 9.3 & 48.4 & 15.7 & 396 & 7.4 & 4.1 & 1087 \\
$8-5$ & 140.5 & 7.4 & 7.3 & 16.6 & 33.0 & 19.0 & 10.1 & 40.4 & 13.4 & 375 & 8.1 & 4.6 & 1324 \\
$11-4$ & 196.0 & 7.7 & 7.5 & 16.2 & 32.7 & 19.1 & 9.7 & 38.7 & 15.7 & 372 & 11.0 & 3.4 & 1296 \\
$14-4$ & 253.0 & 7.4 & 7.4 & 14.7 & 32.2 & 19.0 & 10.1 & 39.7 & 10.1 & 351 & 11.2 & 3.1 & 1381 \\
\hline
\end{tabular}

apunch-in value, shipboard value.

${ }^{b}$ Flow-thru value, shipboard value.

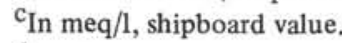

$\mathrm{d}_{\mathrm{In}} \%$, shipboard value.

$$
\begin{aligned}
& { }^{\mathrm{e}_{\text {In }} \%} . \\
& \mathrm{f}_{\text {In mmole/1. }} . \\
& \mathrm{g}_{\text {In ppm. }} \\
& \mathrm{h}_{\text {In } \mu \mathrm{g}-\mathrm{at} .}
\end{aligned}
$$

carried out by AA spectrometry. Standards were prepared by making solutions of 10 to $100 \mathrm{ppm} \mathrm{Sr}$ in distilled water and diluting them in a manner similar to the dilution of the samples.

\section{Potassium}

The manganese solution $(0.5 \mathrm{ml})$ was diluted with 10 $\mathrm{ml}$ of a $5000 \mathrm{ppm}$ La solution. Analysis was carried out with the Perkin-Elmer model 403 spectrometer in the emission mode. Standards were made of 100 to $500 \mathrm{ppm}$ $\mathrm{K}$ in a background of $10,000 \mathrm{ppm} \mathrm{Na}$, carrying through the dilutions as for the samples. Copenhagen IAPSO standard seawater was used as an additional standard.

Accuracies of the various measurements are affected not only by the precision of the methods, but also by the handling of the samples. Also, errors are inevitably introduced in the squeezing process.

\section{DISCUSSION}

\section{Reactions and Changes}

The results presented utilized the following summary of reactions presented by Gieskes (1974).

\section{Dissolved Silica}

This component seems to reflect the mixed-clay mineral assemblages, or the solubility of opal whenever fairly large amounts of opaline biogenous silica are present.

\section{Alkalinity}

Increases are usually due to the production of $\mathrm{HCO}_{3}{ }^{-}$ ions in the bacterial sulfate reduction processes. Decreases seem tied both to the precipitation of carbonates and the "consumption" of alkalinity in reactions involving authigenic silicate formation. 

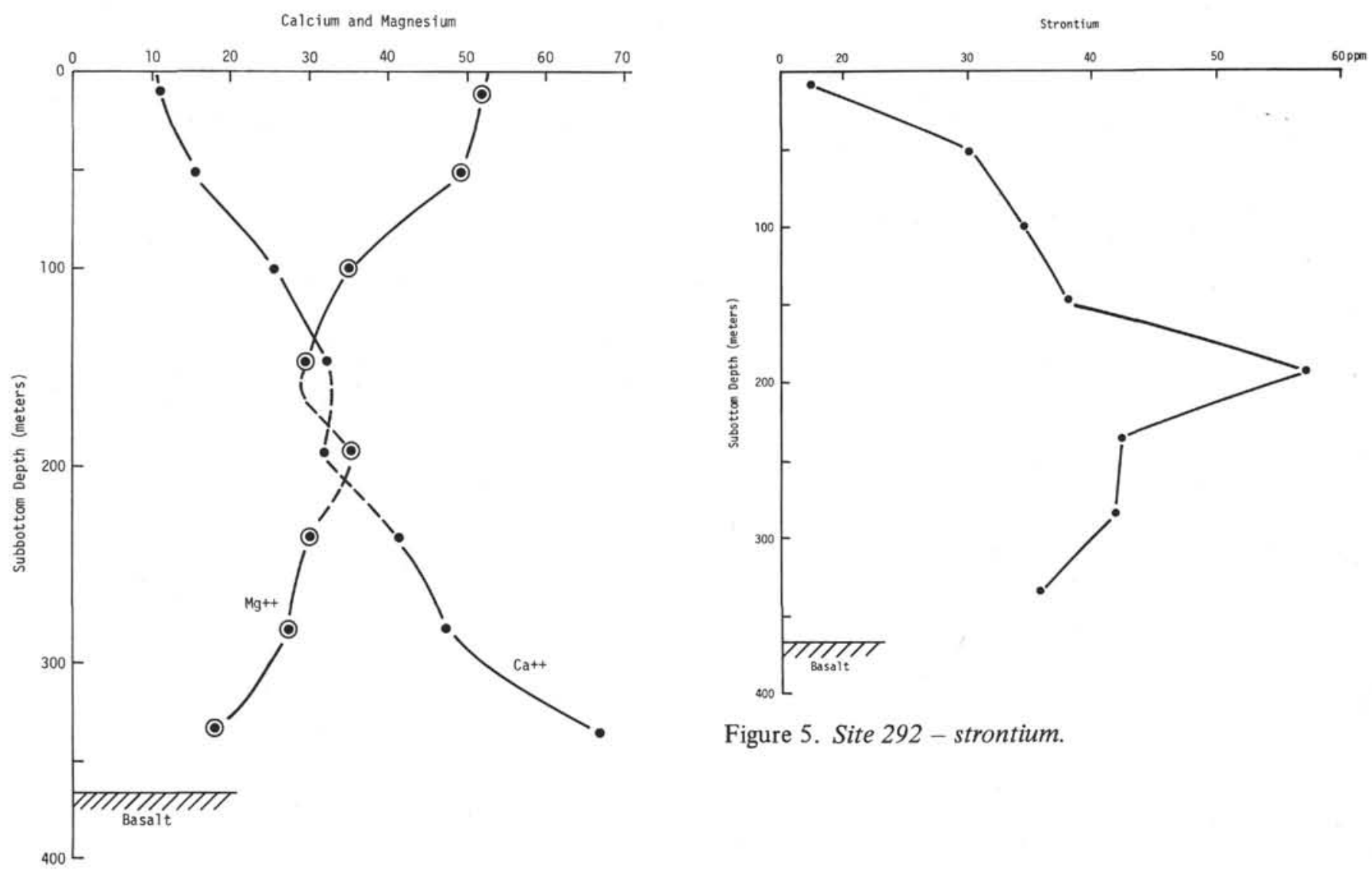

Figure 5. Site 292 - strontium.

Figure 3. Site 292 - calcium and magnesium.

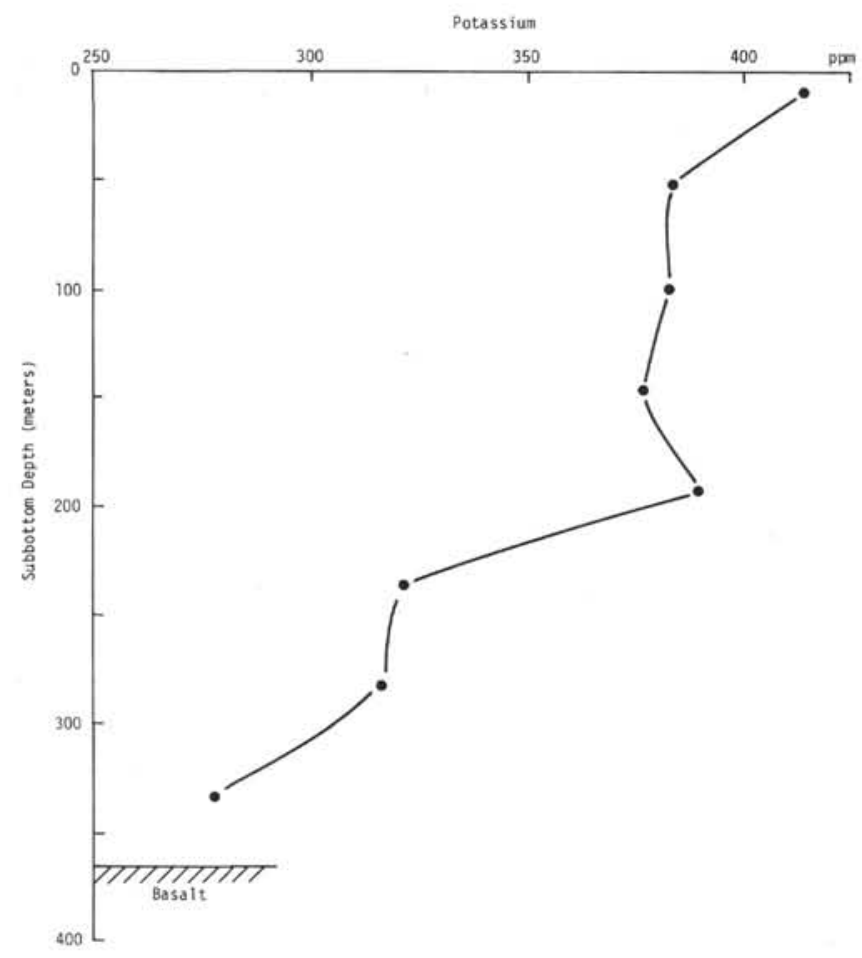

Figure 4. Site 292 - potassium.

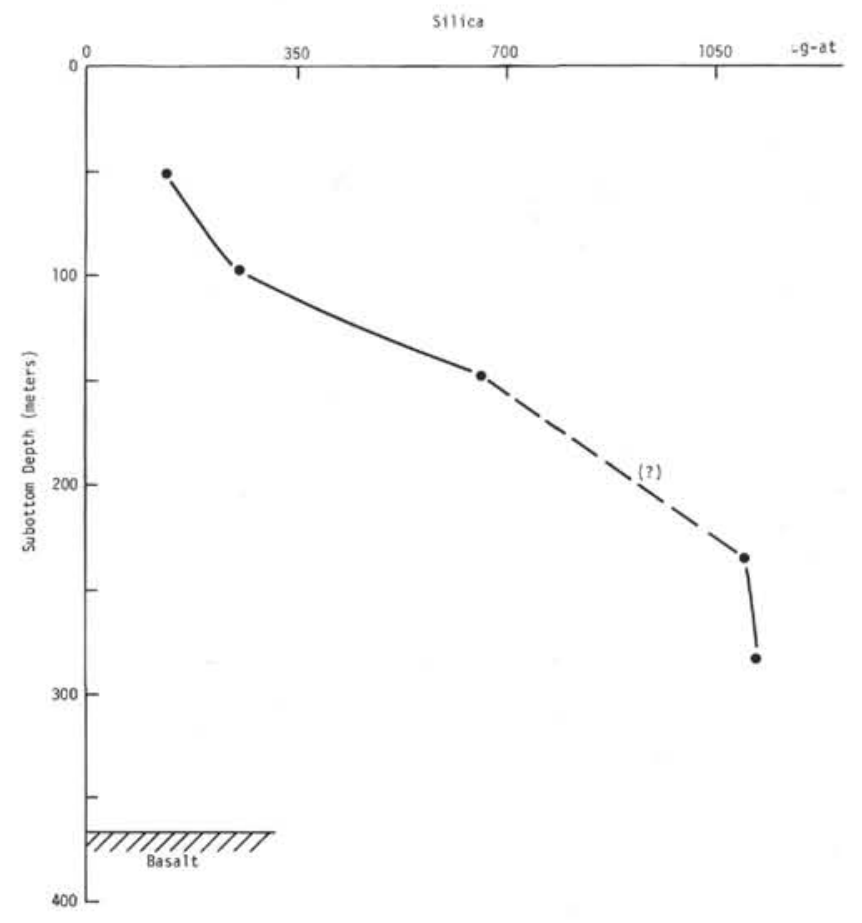

Figure 6. Site 292 - silica. 


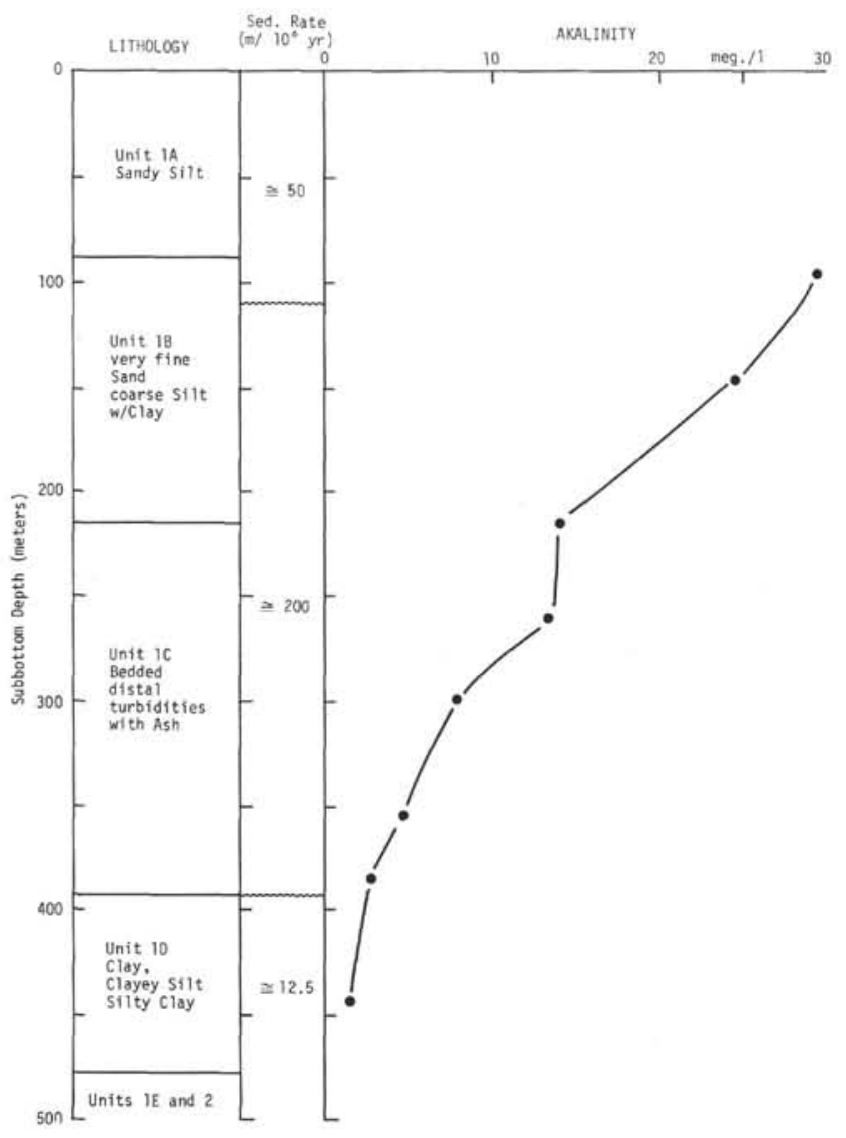

Figure 7. Site 293 - alkalinity.

\section{Sulfate}

Related to bacterial sulfate reduction processes.

Calcium

Calcium carbonate precipitation processes (during sulfate reduction) or the release of calcium during silicate diagenesis.

\section{Magnesium}

Formation of authigenic silicates (palygorskite[?]); formation of intermediate montmorillonites during the alteration of volcanic ash; uptake in recrystallized detrital clay minerals, e.g., chlorite.

\section{Strontium}

Recrystallization of carbonates, aragonitic (tunicate spicules), or calcitic (nannoplankton).

\section{Potassium}

Clay mineral diagenesis and uptake in detrital, poorly crystallized clays, e.g., chlorite.

\section{Manganese}

Dissolved manganese values higher than $0.5 \mathrm{ppm}$ usually imply reducing conditions and are due to the reduction of manganese dioxide phases.

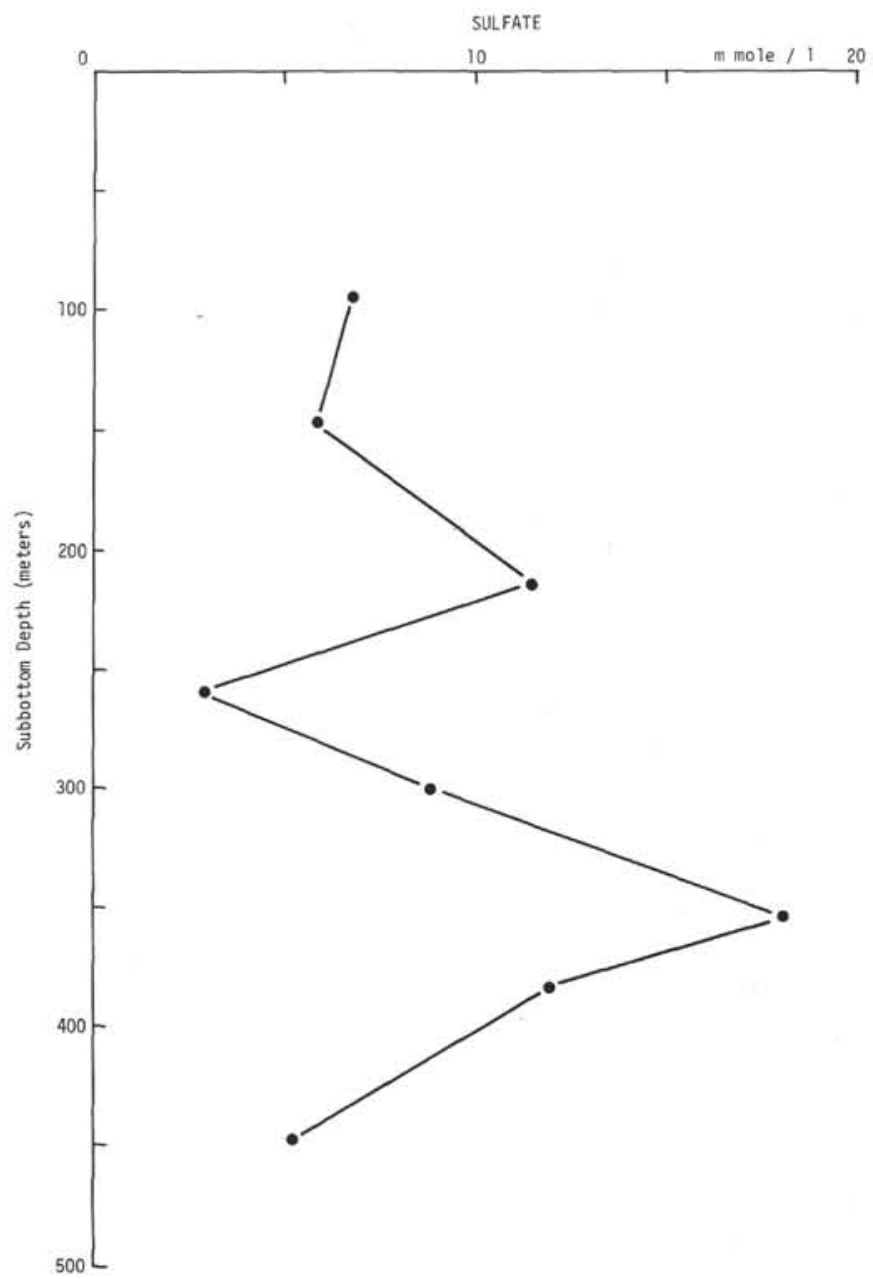

Figure 8. Site 293 - sulfate.

\section{RESULTS}

\section{Site 292}

The geochemical data for Site 292 are tabulated in Table 1 and illustrated in Figures 2-6. Pertinent site data and lithologic descriptions are found in Chapter 4 (this volume).

A brief summary of the grain size, carbon carbonate, and X-ray data for the sediments from Hole 292 shows the following: limited grain size results indicate clayey silts, and silty clays, with sandy silt and sand-silt-clay in Subunit 1B; organic carbon ranges from 0 to $0.2 \%$, with an average of $0.1 \%$ for all subunits; $\mathrm{CaCO}_{3}$ shows a definite increase with depth, reaching $92 \%$ in Subunit 1C; for the X-ray results, chlorite is present in Subunit $1 \mathrm{~A}$, montmorillonite in all subunits (increasing with depth), and clinoptilolite has scattered appearances in all subunits.

Slight trends for $p \mathrm{H}$, alkalinity, and salinity with depth are apparent, but appear to be more discernible deeper than 193 meters (Subunits 1B and 1C) (Table 1). From 193 meters to 334 meters, $p \mathrm{H}$ (in general) and alkalinity decrease with depth, while salinity increases.

An alkalinity maximum at 193 meters (Figure 2) matches extremes for manganese, magnesium, sulfate, 


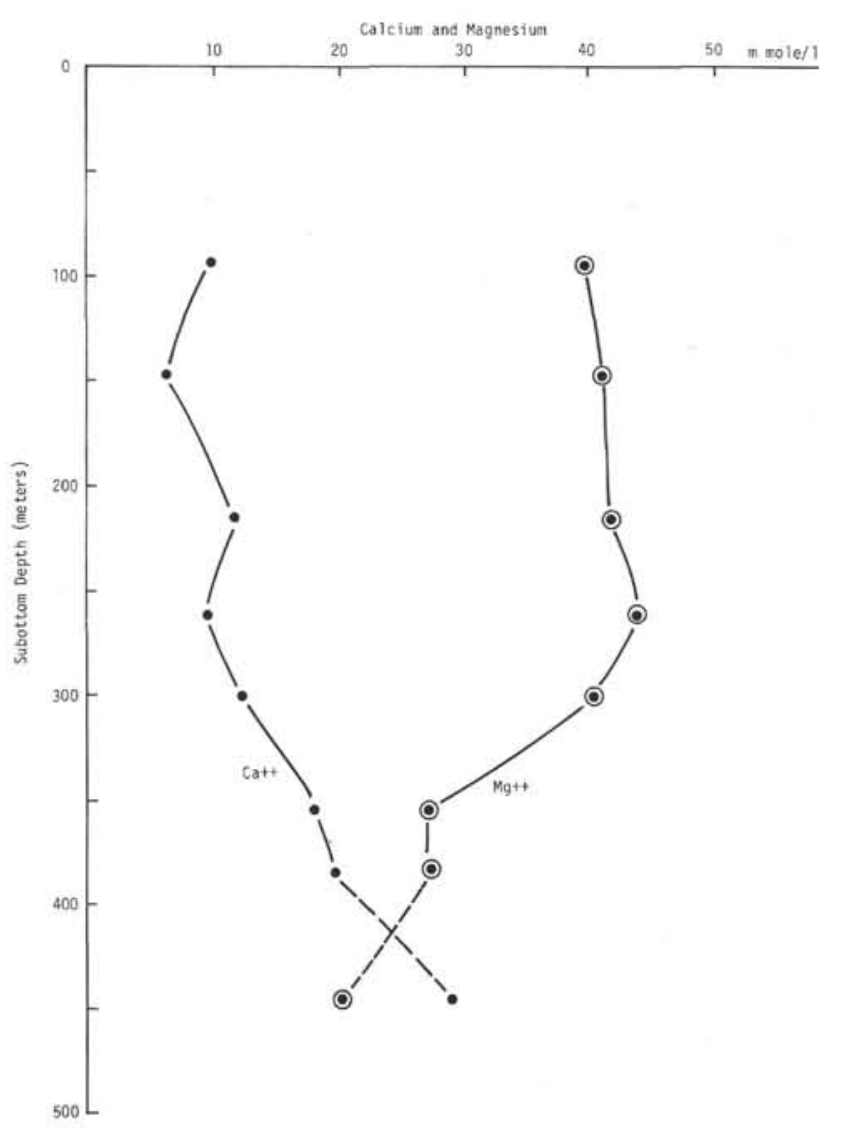

Figure 9. Site 293 - calcium and magnesium.

potassium, and strontium. However, for the value of strontium, these data may reflect seawater contamination.

Silica increases with depth (Figure 6) and reaches a maximum of $1115 \mu \mathrm{g}$-at in Subunit $1 \mathrm{C}(283.5 \mathrm{~m})$. The increased dissolved silica seems indicative of the increase of siliceous fossils which are present below 154 meters, or Core 17. Volcanic ash is also persistently present below 154 meters. The migration of this silica would contribute to the chert found in Subunit 1C.

Sulfate and manganese illustrate some variability, making general trends hard to characterize. Sulfate changes are generally small (Table 1). However, manganese has values exceeding $0.4 \mathrm{ppm}$ at $9.5,147$, and 193 meters. The increase in manganese indicates reducing conditions.

Calcium, magnesium (Figure 3), and strontium (Figure 5), illustrate variability throughout the hole depth. Calcium increases with depth, magnesium decreases, while strontium increases to 193 meters, and in general, decreases to 334 meters. Below 193 meters, the strontium and magnesium curves parallel one another, and calcium shows its highest rate of increase with depth. Silica diagenetic processes seem apparent below 193 meters, as evidenced by lithification and chert zones. This in part may explain the higher calcium levels. The magnesium decrease is possibly indicative of ash devitrification to montmorillonite (see Part V, Appendix

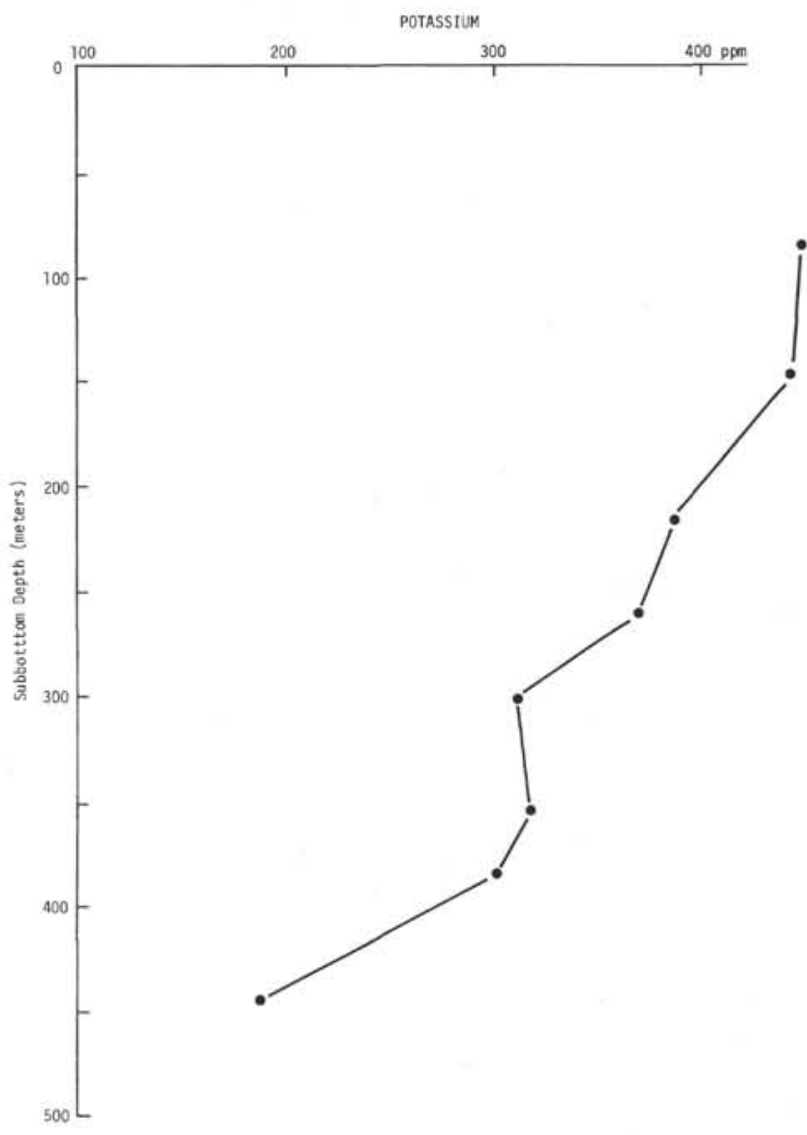

Figure 10. Site 293 - potassium.

I, X-ray results, this volume). Chlorite uptake may also have a role here. Lastly, diagenetic reactions involving conversions of ooze to chalk seem reflected by the strontium values.

Potassium illustrates fairly consistent values, showing a slight decrease with depth to 193 meters (Figure 4). From 193 meters to 334 meters, potassium decreases from 389 to $278 \mathrm{ppm}$, perhaps reflecting ash alteration, clay mineral uptake, and dilution due to an increased sedimentation rate as compared to Subunit $1 \mathrm{~A}$.

\section{Site 293}

Table 2 and Figures 7-11 contain the geochemical data obtained from the sediments at Site 293. Additional site data and lithologic descriptions are found in Chapter 5 (this volume).

Briefly the grain size, carbon carbonate, and X-ray data (Appendix A, Chapter 5) reveal a slight, but apparent decrease in grain size with depth, with clayey sands, sandy silts, and silts in Subunit 1B, with silty clays and clays in Subunits 1D and 1E; organic carbon ranges from $0.1 \%$ to $0.6 \%$, with the higher values $0.2 \%$ to $0.6 \%$ in Subunits $1 \mathrm{~B}$ and $1 \mathrm{C}$. $\mathrm{CaCO}_{3}$ ranges from 0 to $4 \%$; for the X-ray results, mica, chlorite, and montmorillonite are present in all subunits, with montmorillonite increasing with depth. Clinoptilolite is present in Subunits 1B, 1C, and 1D, with phillipsite in Subunit 1D. 


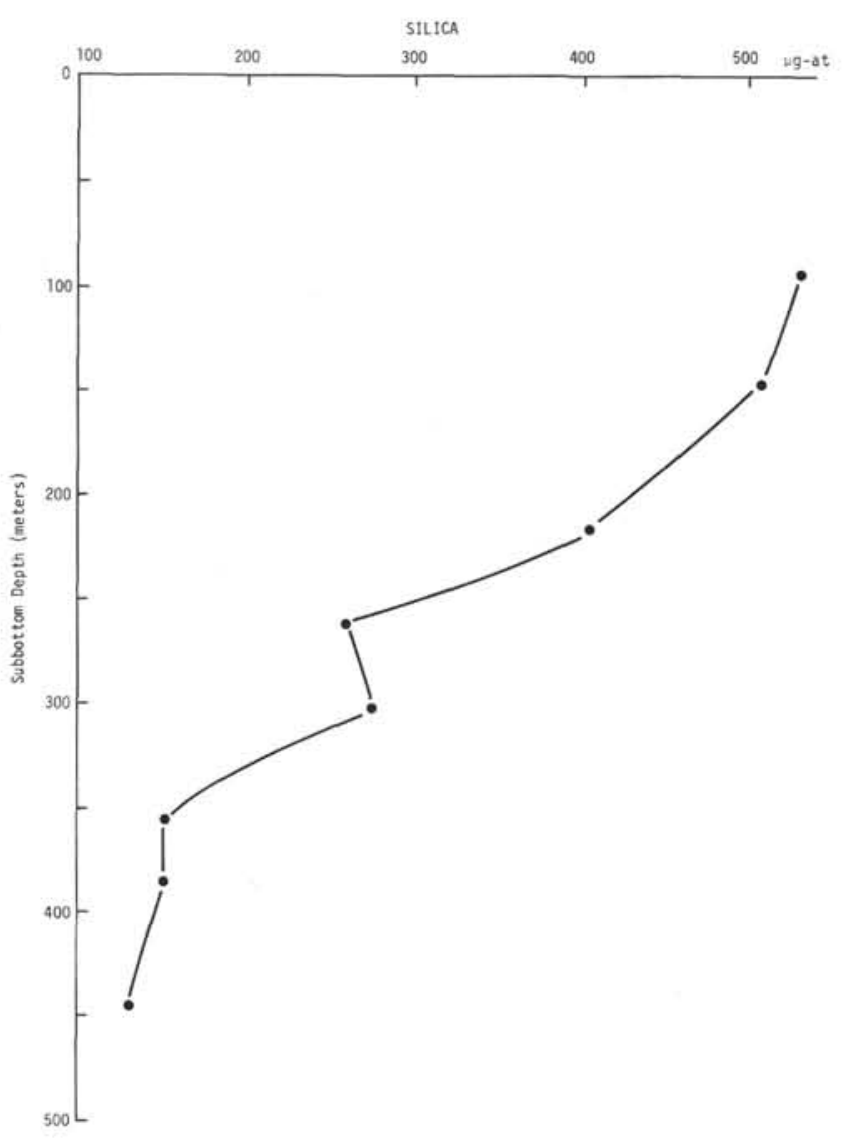

Figure 11. Site 293 - silica.

The $p \mathrm{H}$ shows a slight increasing trend with depth to 444.5 meters (Subunit 1D), with a drop to 7.5 at 503 meters (Table 2). Alkalinity values ranged from 29 to 13 $\mathrm{meq} / 1$ from 94.5 to 261 meters, but all values decreased with depth (Figure 7). Salinity was variable, showing a general decrease with depth (Table 2). The decrease in alkalinity seems most directly related to silica (Figure 11 ), and thus silica diagenesis.

Silica shows a definite decrease with depth (Figure 11 ), perhaps reflecting the increased lithification noted in the deeper subunits. This lithification may, in part, be due to clay mineral diagenesis in the finer grained subunits (ID and 1E). Potassium shows a definite decrease with depth (Figure 10), which may be due to clay mineral uptake.

Data on manganese and sulfate (Figure 8) show nearly converse trends throughout the hole depth. Values for both elements generally range from $<18.1 \mathrm{mmoles} / 1$ for $\mathrm{SO}_{4}$, to $<1.3 \mathrm{ppm}$ for $\mathrm{Mn}$. Four manganese values exceed $0.4 \mathrm{ppm}$ and match low sulfate values, thus implying reduction throughout the section.

Calcium and strontium increase slightly with depth, with exceptions, while magnesium decreases with depth (Figure 9). Because of the low carbonate content, the variations of these elements seem due to clay mineral recrystallization, and perhaps alteration of ash. A significant break in the trends is present at 261 meters.

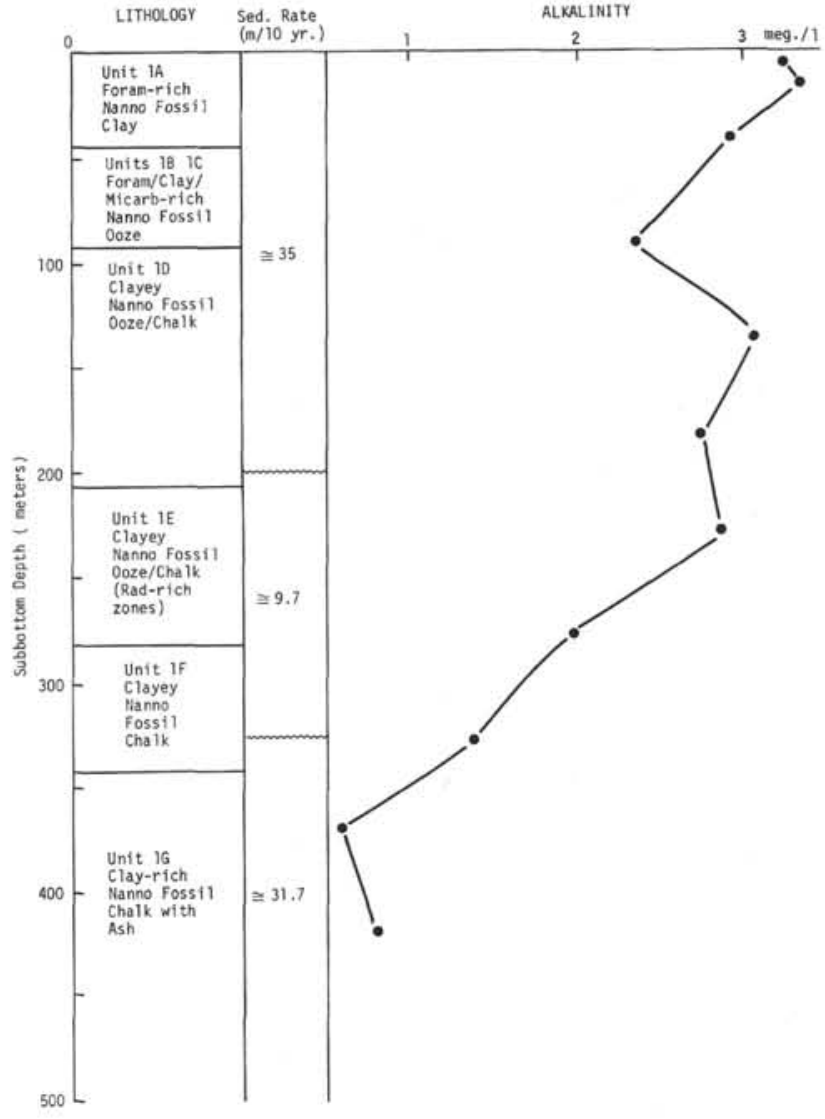

Figure 12. Site 296 - alkalinity.

Below this depth, calcium and strontium show a higher rate of increase with depth, while magnesium shows a higher rate of decrease with depth.

\section{Site 296}

Table 3 and Figures 12-14 contain the geochemical data obtained from the sediments at Site 296. Additional site data and lithologic descriptions are found in Chapter 7 , this volume.

The grain sizes of the sediments range from sand to clay. The sands (sandy silt, silty sands, sand) dominate in Subunit 1E. Organic carbon contents range from 0 to $0.4 \%$, with Subunit $1 \mathrm{~A}$ having the higher percentages. $\mathrm{CaCO}_{3}$ values are variable, ranging from $2 \%$ to $79 \%$, with Subunits $1 \mathrm{C}$ and $1 \mathrm{D}$ having the higher contents. The X-ray results show chlorite present in Subunits $1 \mathrm{~A}$, 1C, 1D, and 1E; clinoptilolite in Subunit 1E; and kaolinite in Subunit 1D.

$p \mathrm{H}$ values range from 7.0 to 7.6 from 4.5 to 327.5 meters (Table 3 ), increasing sharply to values exceeding 8.0 from 369 to 549.5 meters. Alkalinity decreases with depth to 327.5 meters, and then increases with depth to the bottom of the hole (Figure 12). Salinity values are also higher and increase with depth below 327.5 meters. This 327.5-meter depth is in the interval where lithologies of Subunit 1G change from clayey nannofossil chalks to clay-rich nannofossil chalks, and a 


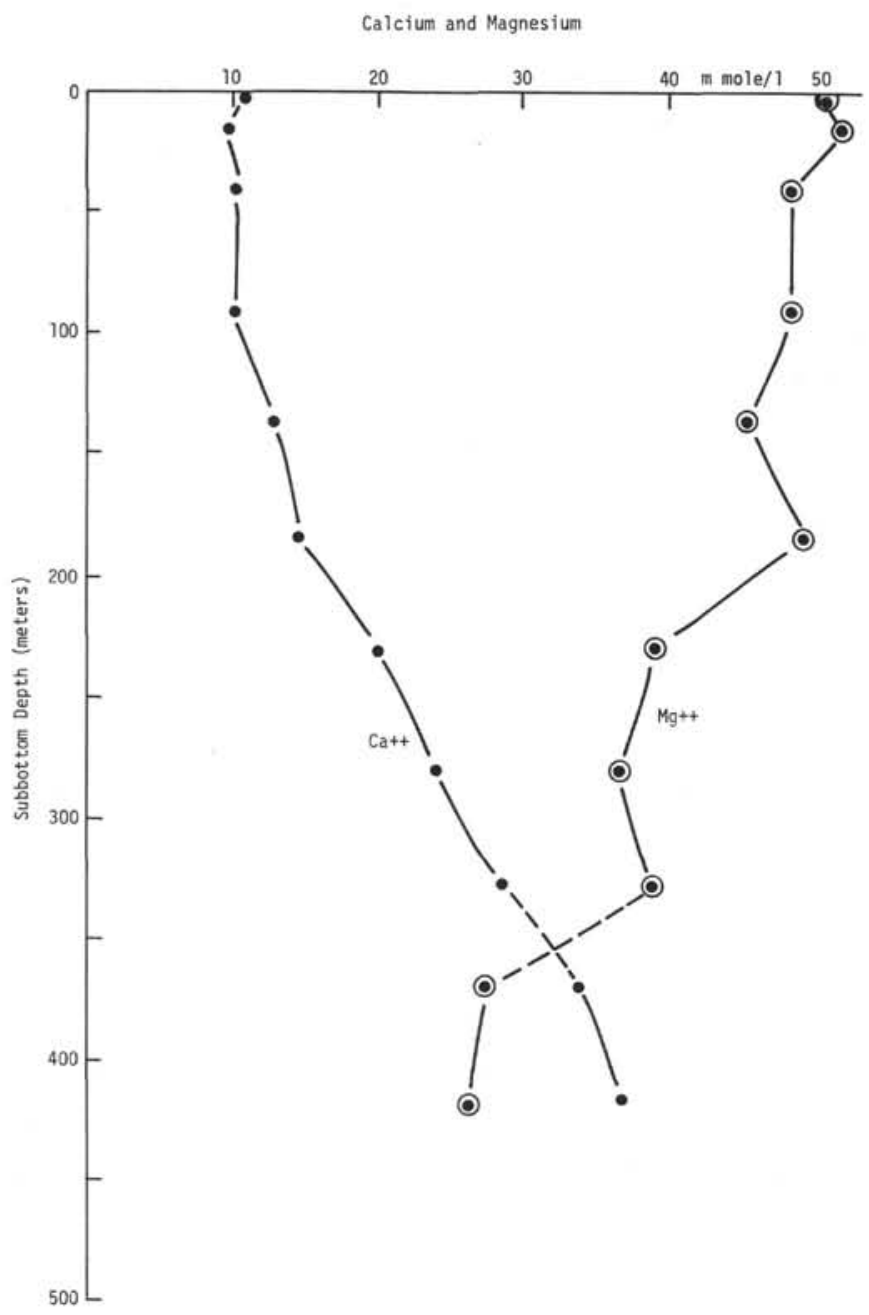

Figure 13. Site 296 - calcium and magnesium.

significant increase in volcanic ash interbeds is noted. Significantly, the X-ray results (Part V, Appendix I) show rather distinct mineralogical changes starting at 331.9 meters.

The alkalinity shows a slight increase from the surface value to 14 meters, but thereafter shows a general decrease to 327.5 meters (Figure 12). The decrease may be related to silica diagenesis, which also is evidenced by the decrease in magnesium and increase in calcium with depth (Figure 13).

Silica values were recorded for only 6 of the 12 samples (Table 3). The trend for these values is one of an increase with depth, particularly in Subunits $1 \mathrm{E}$ and $1 \mathrm{~F}$ (Table 3 ). Notably radiolarians and volcanic ash beds become increasingly prevalent starting at 206 meters (Subunit 1E). Potassium values range from 365 to 467 $\mathrm{ppm}$ and illustrate variability throughout the hole depth (Table 3), with a tendency to increase with depth.

Manganese values are high in the upper 229 meters, ranging from a high of $9 \mathrm{ppm}$ at 4.5 meters, decreasing to a low of $1.1 \mathrm{ppm}$ at 134.5 meters, and then increasing to $3.7 \mathrm{ppm}$ at 229.5 meters. From 229.5 to 418 meters, values average $0.6 \mathrm{ppm}$. There is little correspondence of manganese with sulfate. The sulfate values vary little

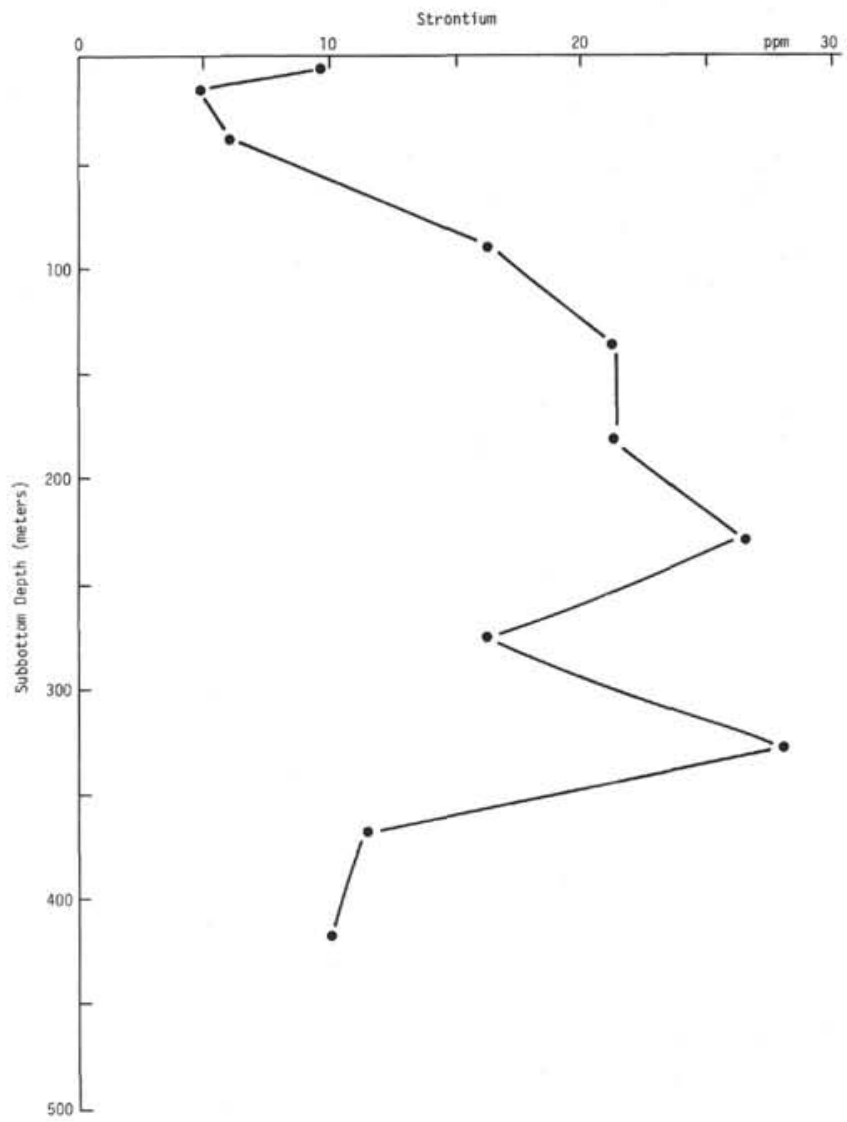

Figure 14. Site 296 - strontium.

from 4.5 meters to 229.5 meters (23.6-28.8 mmoles/1), but increase in the 229.5 to 418 meter interval (Table 3 ). The gray (green-olive) coloration of the subunits to 206 meters, and the manganese-sulfate values and trends, may indicate reduction processes in these upper subunits.

Calcium illustrates a nearly linear increase with depth, with a somewhat higher rate occurring from 278.5 to 418 meters (Figure 13). Magnesium tends to linearly decrease with depth, except for a high value (49.3) at 182 meters, and another (38.8) at 327.5 meters (Figure 13). These depths correspond to two potassium depletion zones, thus seemingly being an indication of clay mineral diagenesis. The general magnesium decrease below 206 meters reflects sedimentation rates, and uptake, possibly by chlorite and/or other clay minerals. Strontium to some degree parallels the calcium trend to 229.5 meters, but thereafter parallels the magnesium trend to the bottom of the hole (Figure 14). The strontium trend most probably reflects the recrystallization of carbonate in the ooze-chalk units.

\section{Site 297}

The geochemical data for Site 297 are tabulated in Table 4 and graphically illustrated in Figures 17-20. Chapter 8 (this volume) contains additional site data and lithologic descriptions.

Pertinent X-ray, grain size, and carbon carbonate data show the following for the sediments from Site 


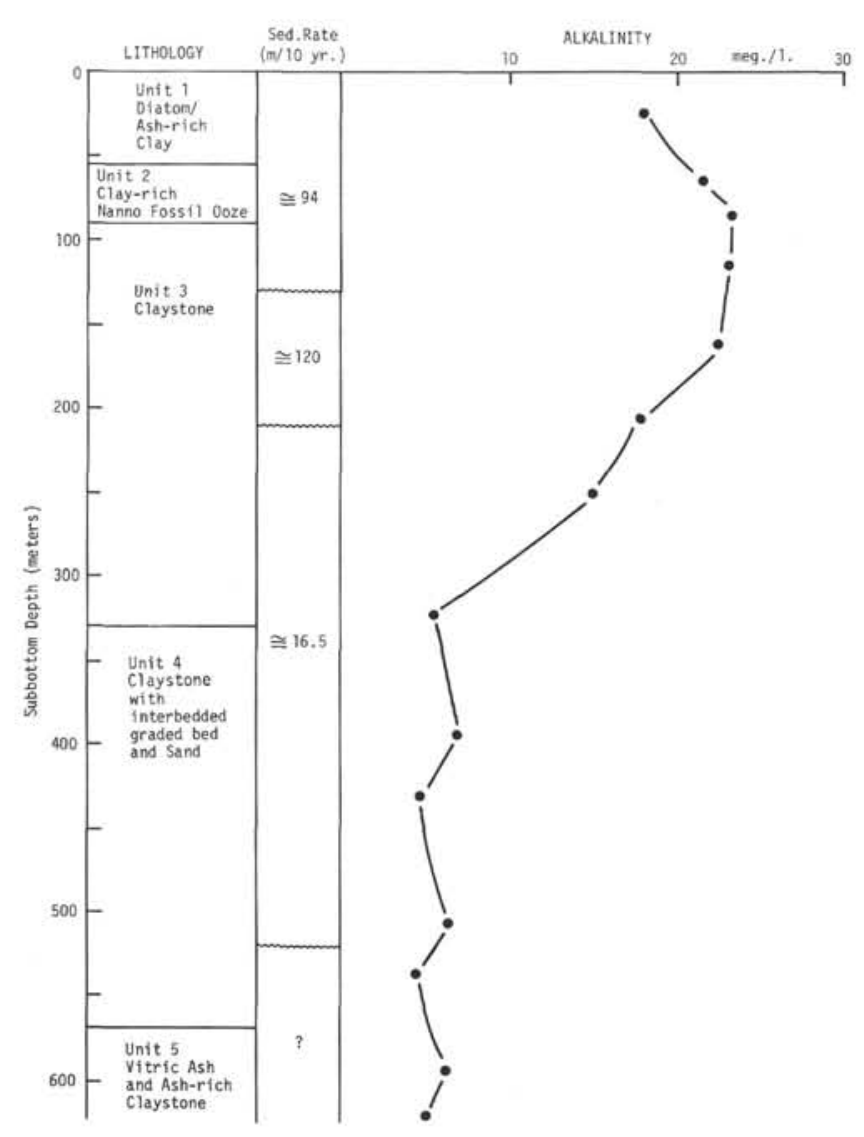

Figure 15. Site 297-alkalinity.

297: a dominance of silty clays for all units, except for Unit 5 (clayey silts), and sand and silt in Unit 4; organic carbon ranges from $0.3 \%$ to $0.5 \%$, and $\mathrm{CaCO}_{3}$ from $1 \%$ to $15 \%$ in Units $1-3$; chlorite is a sediment constituent in the units, pyrite appears in Unit $1(42.8 \mathrm{~m})$.

$p \mathrm{H}$ varies between 7.2 and 8.2 over the 21.5 to 507.5 meter depths. From 507.5 meters to 666 meters, the $p \mathrm{H}$ increases with a high value of 8.6 at 666 meters. One exception to this trend occurs at 594.5 meters (Table 4). All alkalinity values, except one, exceed $4.0 \mathrm{meq} / 1$. They range from a high of $23.17 \mathrm{meq} / 1$ at 84.5 meters, to a low of $2.64 \mathrm{meq} / 1$ at 666 meters (Table 4, Figure 15). With exceptions, the values decrease with depth. The salinity, again with exceptions, decreases with depth.

Silica values exceed (except at $84.5 \mathrm{~m}) 800 \mu \mathrm{g}$-at, generally increasing to 205 meters (Unit 3); decreasing to $965 \mu \mathrm{q}$-at at 393.5 meters (Unit 4), with a sharper decrease to $270 \mu \mathrm{g}$-at at 536.5 meters (Unit 4). From 536.5 to 594.5 meters, the values increase to $446 \mu \mathrm{g}$-at (Figure 20). The values seem to correlate with the lithology and the general lack of siliceous fossils in most units below Unit 1: high values in Unit 1 (diatom-rich clay); high in Unit 3 (claystone), reflecting clay mineral reaction; low in Unit 2 (nannofossil ooze) and Unit 4 (claystone), reflecting lithification. The slight increase between 536.5 to 594.5 meters probably indicates devitrification of the vitric ash and ash-rich claystone of Unit 5.

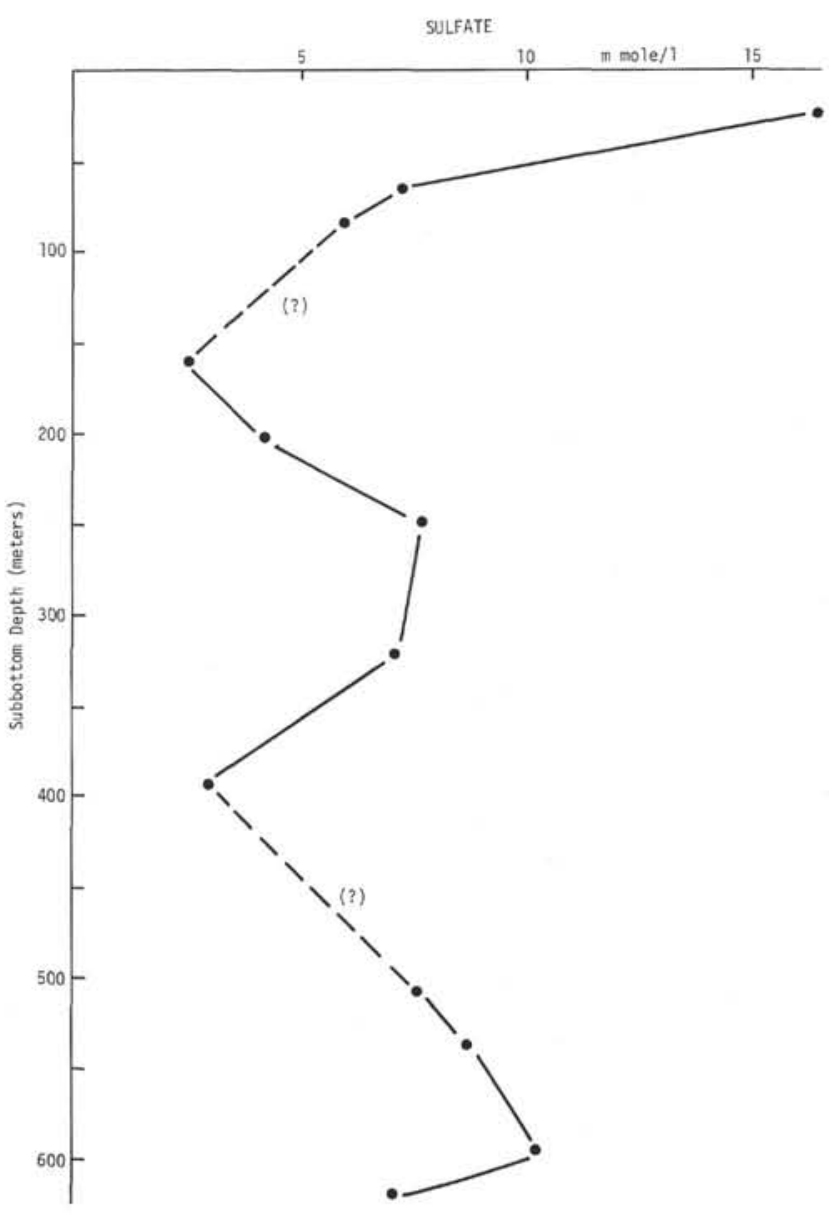

Figure 16. Site 297 - sulfate.

Potassium in general decreases with depth, from 427 ppm at 21.5 meters to $259 \mathrm{ppm}$ at 536.5 meters (Figure 18). The general depletion perhaps reflects uptake in clay mineral diagenesis. Chlorite is a mineral component in all units (Part V, Appendix I, this volume).

Sulfate (Figure 16) and manganese have high values at 21.5 meters (16.4 mmoles/1 and $5.1 \mathrm{ppm}$, respectively). Peat was noticed scattered through this core (Core 3 ), thus these values probably reflect a reduction process. From this depth, manganese ranges from 1.8 to 0.0 , with values of 1.4 to 1.8 reported at 160.5 and 251.0 meters (Unit 3) (Table 4). Peat fragments, bioturbation, and pyritized burrows were again noted.

Calcium and strontium increase with depth with the trends of both elements about parallel, except as noted in Figures 17 and 19. Magnesium decreases almost linearly with depph (Figure 17). Calcium and strontium are converse in their trends to silica, erhaps reflecting silica diagenesis, and precipitation with depth. Recrystallization of clay minerals (chlorite) may also play a role in the depletion of magnesium.

\section{Site 299}

Table 5 contains the geochemical data obtained from the analysis of sediments from Site 299 . These data are also illustrated in Figures 21-25. Additional site data 


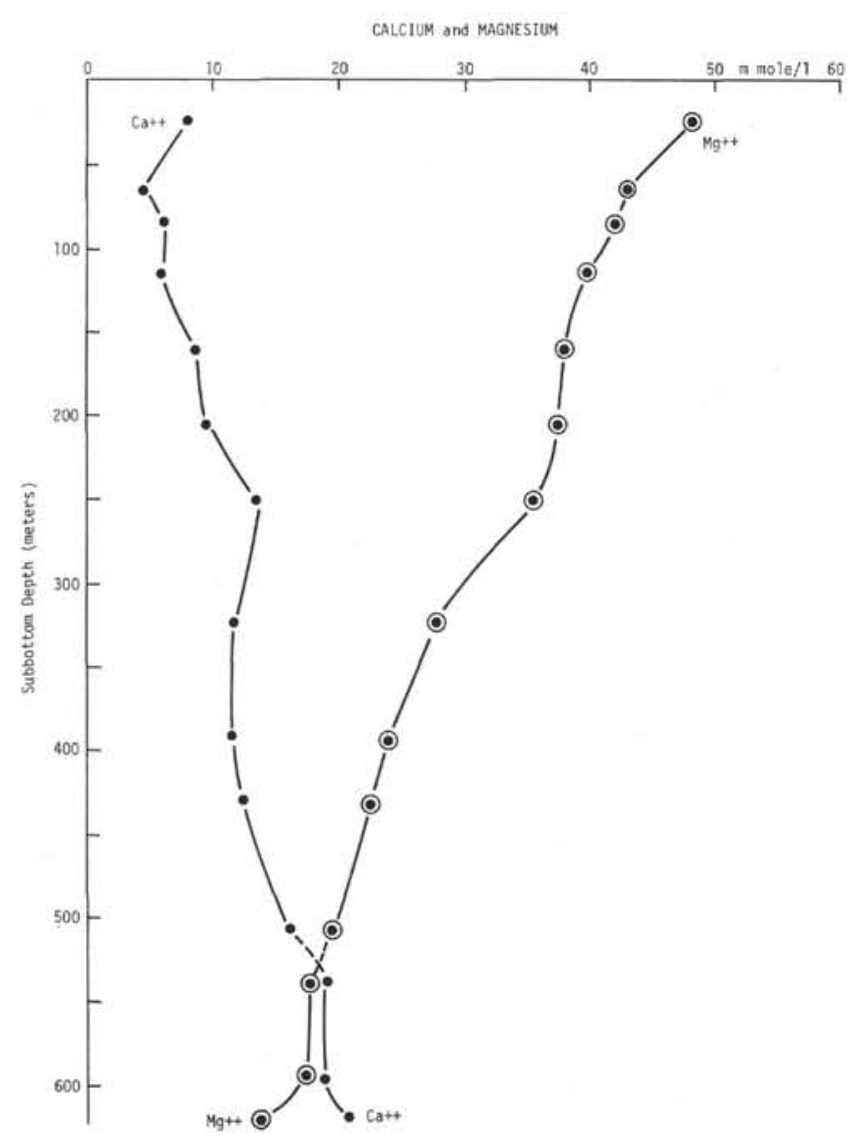

Figure 17. Site 297 - calcium and magnesium.

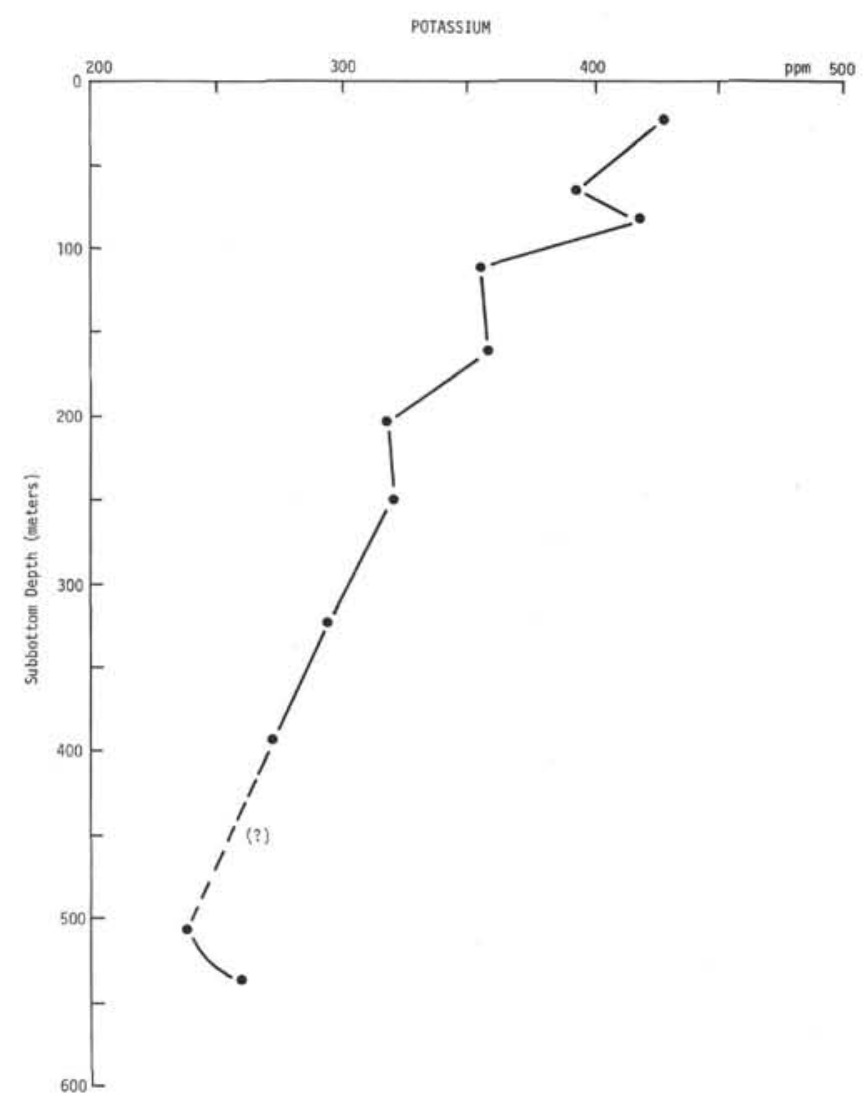

Figure 18. Site 297 - potassium.

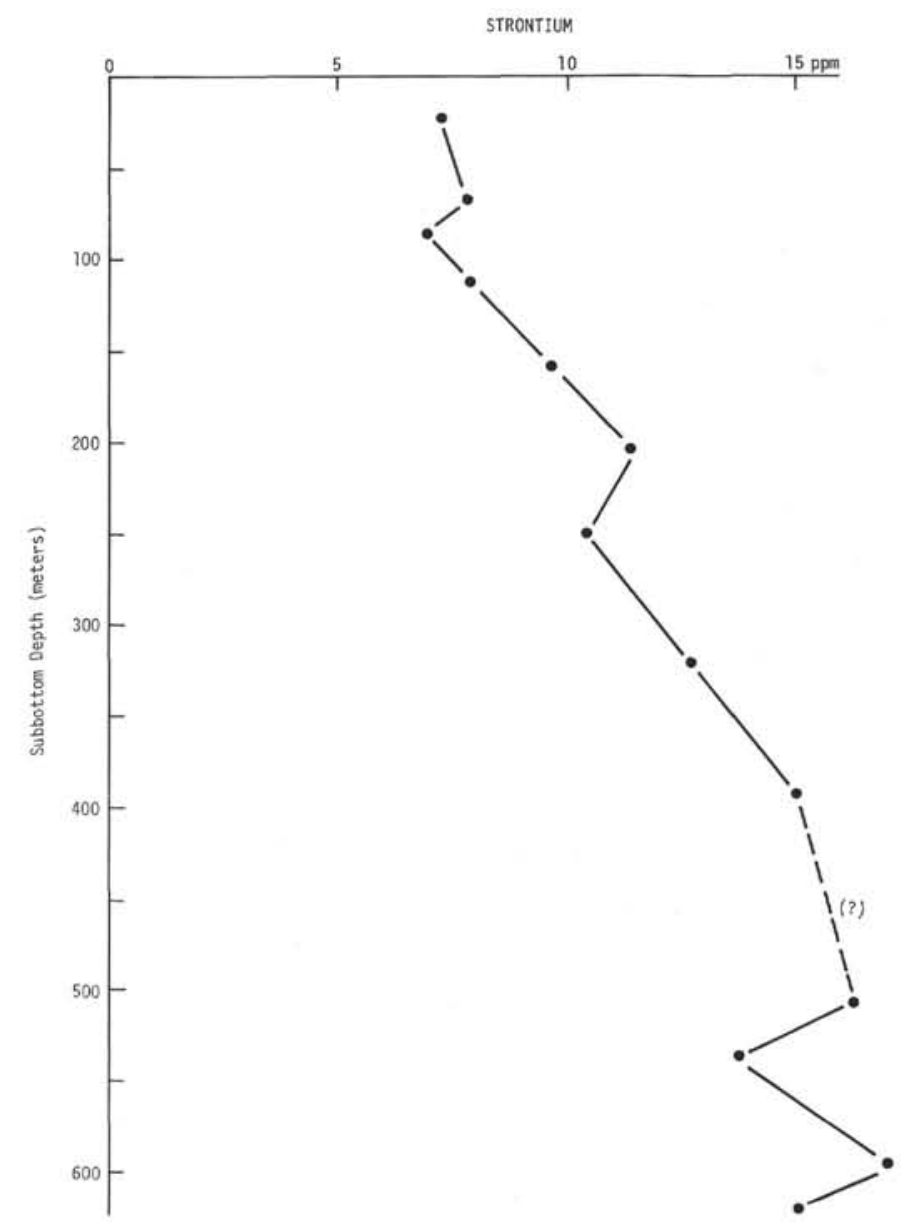

Figure 19. Site 297 - strontium.

and lithologic descriptions are found in Chapter 10 (this volume).

X-ray, grain size, and carbon carbonate data (Chapter 10, Appendix A) show the following characteristics: a range of grain sizes from sand to silty clays. Only Units $1 \mathrm{~B}, 2$, and 5 contain sand; the organic carbon content ranges from $0.3 \%$ to $3.1 \%$, with $3.1 \%$ found in Subunit $1 \mathrm{~A}, 1.0 \%$ in Subunit 1B, and $1.2 \%$ in Unit 3; calcium carbonate values range from $1 \%$ to $25 \%$; characteristic for the X-ray analyses are dolomite at 54.5 meters and chlorite and pyrite in all units.

$p \mathrm{H}$ values decrease to 139 meters, but then increase with depth to 497 meters. Seven of eight alkalinity values exceed $4.0 \mathrm{meq} / 1$. A decrease in alkalinity with depth begins at 183.5 meters, with values above that depth variable between highs ( 22 and $29 \mathrm{meq} / \mathrm{l})$ and lows (10 and $20 \mathrm{meq} / \mathrm{l})$ (Table 5, Figure 21). With exceptions, the salinity is unvarying with depth (Table 5).

Dissolved silica shows two maxima (139 and $329 \mathrm{~m}$ ), with minima at 7.5 and 400.5 meters (Figure 25). The maximum values, and other high silica values correspond to those cores showing a relatively high diatom content.

Potassium illustrates a near linear decrease with depth (Figure 24). The depletions may be a function of the sedimentation rate (48-116 m/m.y.), as well as uptake by clay minerals in these detrital sediments. 


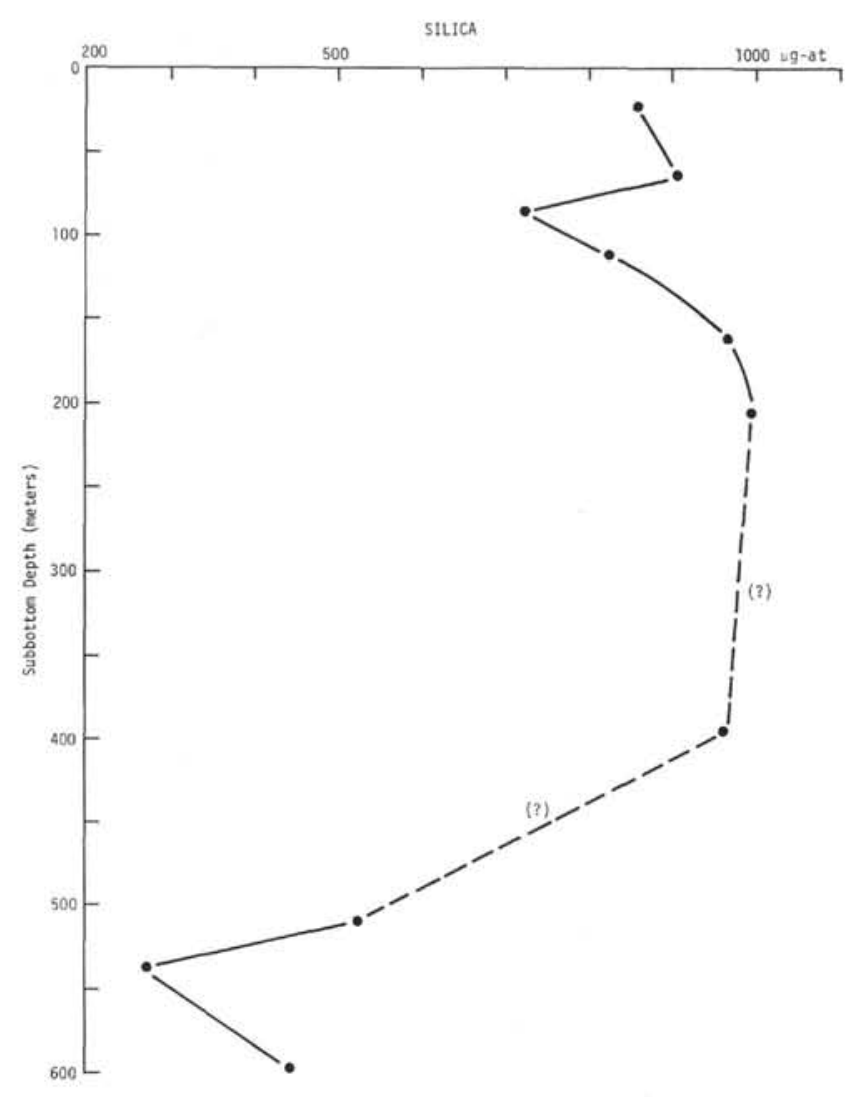

Figure 20. Site 297 - silica.

Except for a value of $4.3 \mathrm{ppm}$ manganese at 7.5 meters, all other values range between 0.0 and $0.8 \mathrm{ppm}$. It would seem that reducing conditions are implied only in the upper few meters; however, the high sedimentation rate may cause a low value in spite of reducing conditions. The high sulfate at 7.5 meters is in part due to interstitial seawater contamination, but the decrease with depth and correspondence to alkalinity indicate reduction processes at depth (Figure 22). A sulfate maximum occurs at 139 meters matching minimum values in $p \mathrm{H}$, strontium, and alkalinity, and maximum values (or increases) in calcium, magnesium, and silica.

Calcium (Figure 23), strontium, and magnesium (Figure 23) show extreme variation from 7.5 to 139 meters. Deeper than 139 meters, calcium increases and magnesium decreases, while strontium increases to 329 meters, decreasing thereafter to 497 meters.

The magnesium trend seems related to the chlorite content which shows the similar trends (Part V, Appendix I, this volume).

\section{Site 302}

Geochemical data from Site 302 are tabulated in Table 6 and graphically presented in Figures 26-29. Site report data and lithologic descriptions are found in Chapter 13 (this volume).

The X-ray, grain size, and carbon carbonate data (Chapter 13, Appendix A) illustrate the following: a dominant grain size of silty clays for Units 1-3; Unit 4

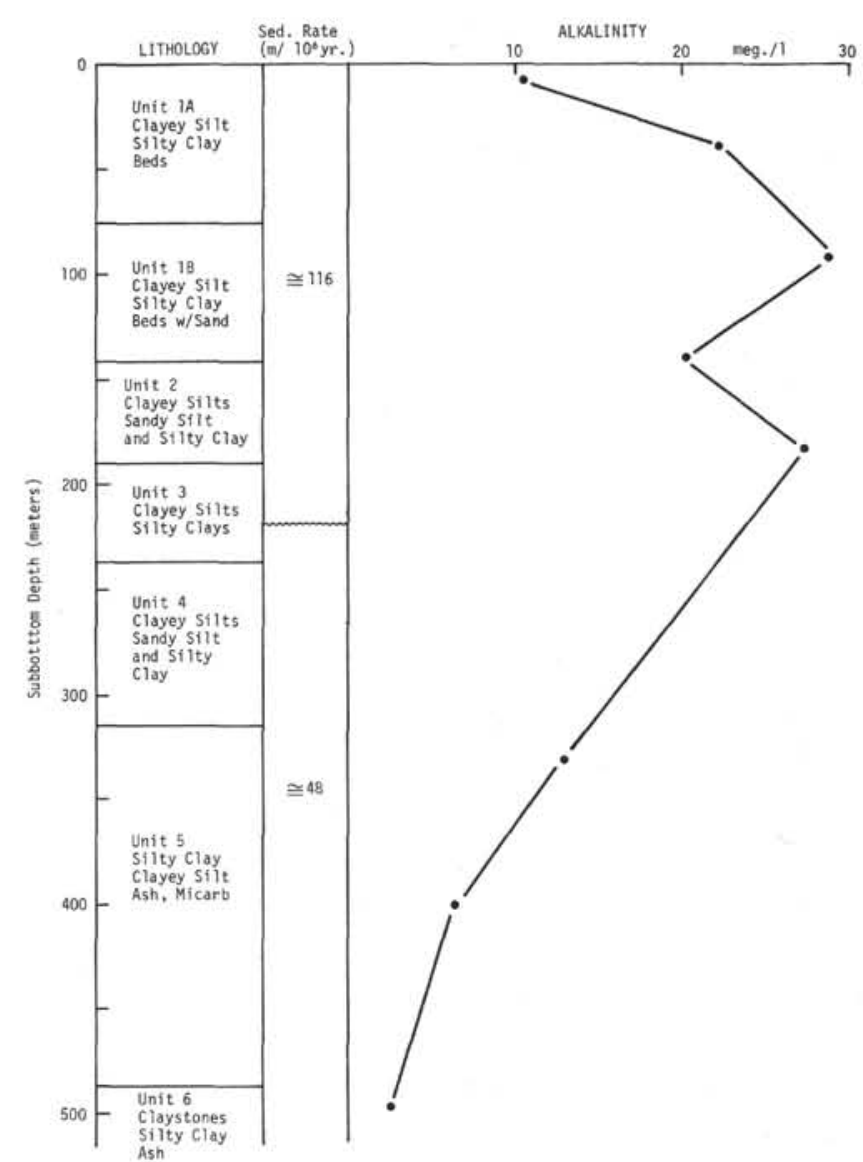

Figure 21. Site 299 - alkalinity.

recorded a clay; organic carbon contents range from 0.4 to $0.7 \%$, with a range of $0-6 \% \mathrm{CaCO}_{3}$; pyrite and chlorite are notable constituents (X-ray) in all sedimentary units, with cristobalite and tridymite present in Unit 4.

$p \mathrm{H}$ values are variable throughout the hole depth and do not illustrate a consistent trend with depth. The range of values is 7.2 to 7.7 (Table 6). The alkalinity shows values ranging from 12.9 to $16.6 \mathrm{meq} / 1$ from 26.5 to 253 meters. The lowest value is $2.15 \mathrm{meq} / \mathrm{l}$ at 457.5 meters (Unit 4) (Figure 26). The salinity shows a near linear decrease with depth.

The high alkalinity values, the sulfate and manganese values, the organic carbon contents, the presence of pyrite, and shows of gas (methane and ethane) during drilling are indicative of sulfate reduction processes at least in Units 1-3.

Silica shows a fairly definite increase with depth, with a slight decrease at 196 meters (Figure 29). The silica increase reflects the opaline biogenous silica in the dominant diatom ooze lithologies.

Potassium shows a slight linear decrease with depth, ranging from a high of $402 \mathrm{ppm}$ at 26.5 meters to a low of $351 \mathrm{ppm}$ at 253 meters. Sedimentation rates are high $(12-76 \mathrm{~m} / \mathrm{m} . \mathrm{y}$.) and may be causing the depletion, along with clay mineral uptake. Montmorillonite and kaolinite were reported in the X-ray analyses.

Manganese values are high (3.1-4.6 ppm) and show a slight tendency to decrease with depth. Combined with 


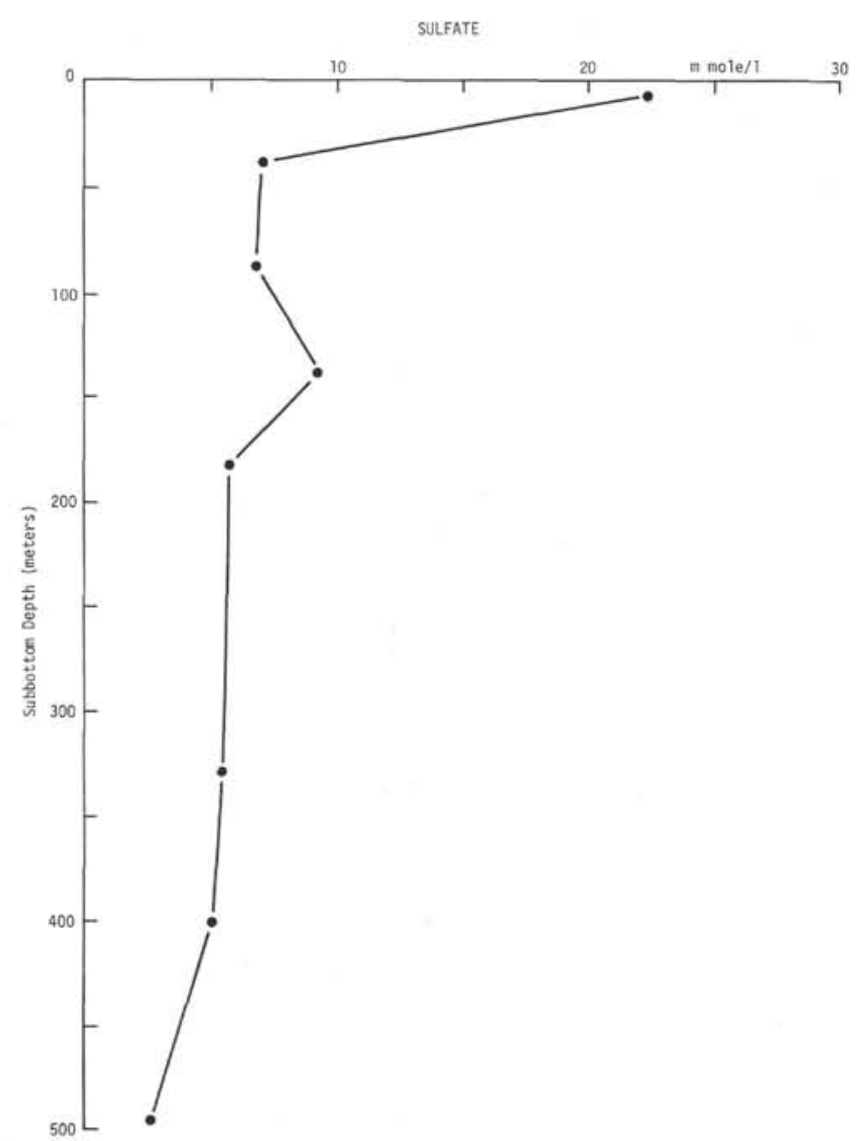

Figure 22. Site 299 - sulfate.

the sulfate values and sulfate values that decrease with depth (Figure 28) and the high alkalinity, sulfate reduction processes are indicated.

Calcium shows a small range of values (9.3-10.1 mmole/1) and little variation with depth. A small number of micarb zones was noted in Units 1-3. Magnesium, with a value of $46.8 \mathrm{mmole} / 1$ at 26.5 meters, shows an increase at 82 meters, a decrease at 196 meters, and increases slightly again to 253 meters (Figure 27). Chlorite is a mineral component in these sediments and is probably related to the lower magnesium contents through uptake. The increases may relate to devitrification of ash, noted in the sediments.

The strontium trend is opposite from that of magnesium, increasing with depth. The content is possibly related to carbonate recrystallization.

\section{ACKNOWLEDGMENTS}

Special thanks go to Joris Gieskes, Scripps Institution of Oceanography, who not only read and critically reviewed this paper, but also guided the analysis program. Jan Hillson, graduate student, Scripps Institution of Oceanography, performed the chemical element analyses. The author also ex-

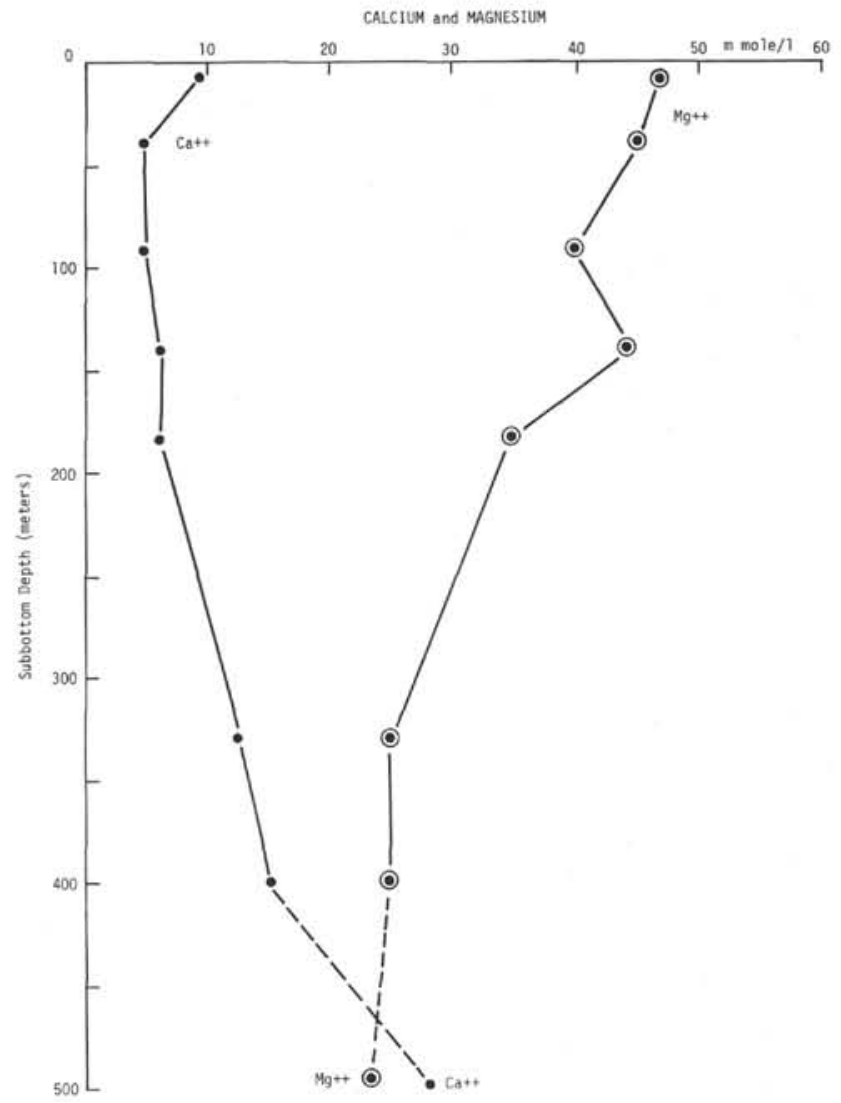

Figure 23. Site 299 - calcium and magnesium.

presses his appreciation to Tracy Vallier, who also reviewed the manuscript.

\section{REFERENCES}

Carpenter, J. H. and Manella, M. E., 1973. Magnesium to chlorinity ratios in seawater: Limnol. Oceanogr., v. 78, p. 3621-3626.

Cescon, B. S. and Macchi, G. R., 1973. A microvolumetric determination of sulfate in pore waters. In Heezen, B. C., MacGregor, I. G., et al., Initial Reports of the Deep Sea Drilling Project, Volume 20: Washington (U.S. Government Printing Office), p. 811-812.

Gieskes, J. M., 1973. Interstitial water studies, Leg 15. Alkalinity, $p \mathrm{H}, \mathrm{Mg}, \mathrm{Ca}, \mathrm{Si}, \mathrm{PO}_{4}$, and $\mathrm{NH}_{4}$. In Heezen, $\mathrm{B}$. C., MacGregor, I. G., et al., Initial Reports of the Deep Sea Drilling Project, Volume 20: Washington (U.S. Government Printing Office), p. 813-829.

1974. Interstitial water studies, Leg 25. In Simpson, E. W. S., Schlich, R., et al., Initial Reports of the Deep Sea Drilling Project, Volume 25: Washington (U.S. Government Printing Office), p. 361-394.

Strickland, J. D. H. and Parsons, T. R., 1968. A manual for seawater analysis: Fish. Bd. Canada Bull., v. 167.

Tsunogai, S., Nishimura, M., and Nakaya, S., 1968. Complexometric titration of calcium in the presence of large amounts of magnesium: Talanta, v. 15, p. 385-390. 


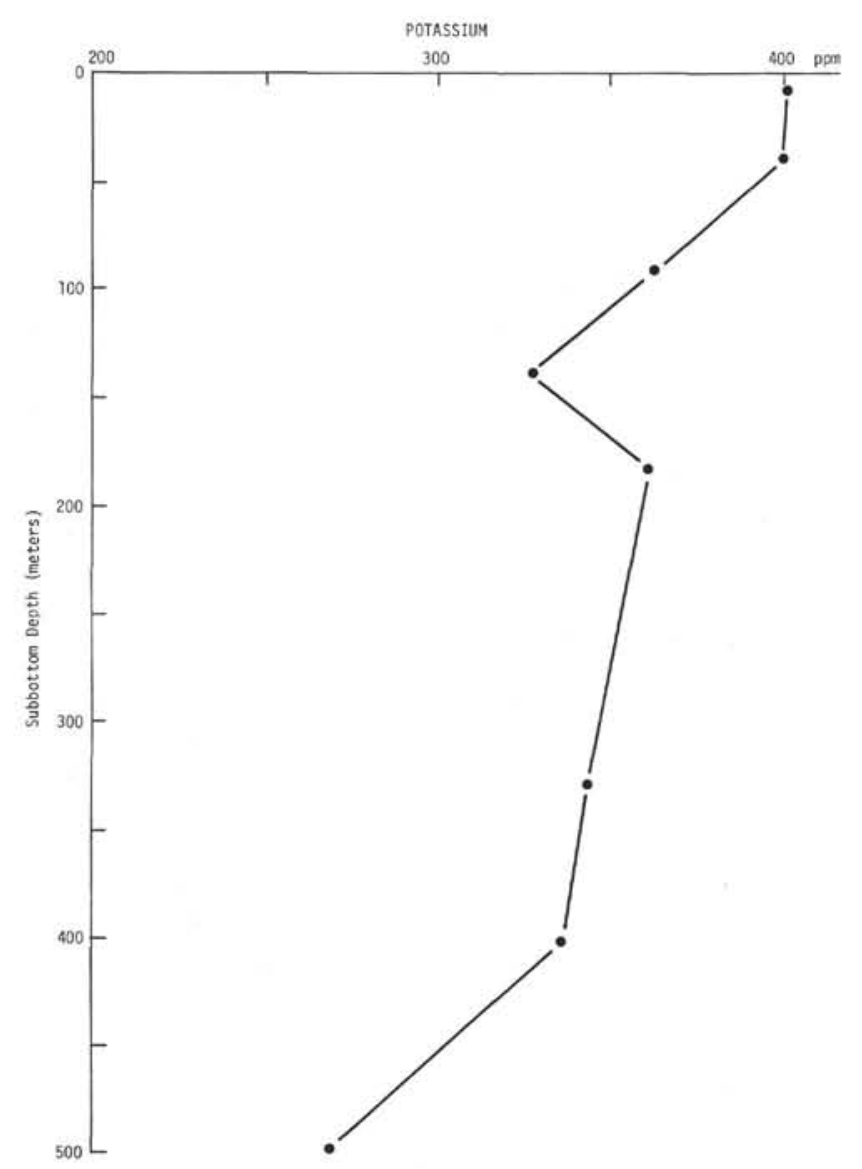

Figure 24. Site 299 - potassium.

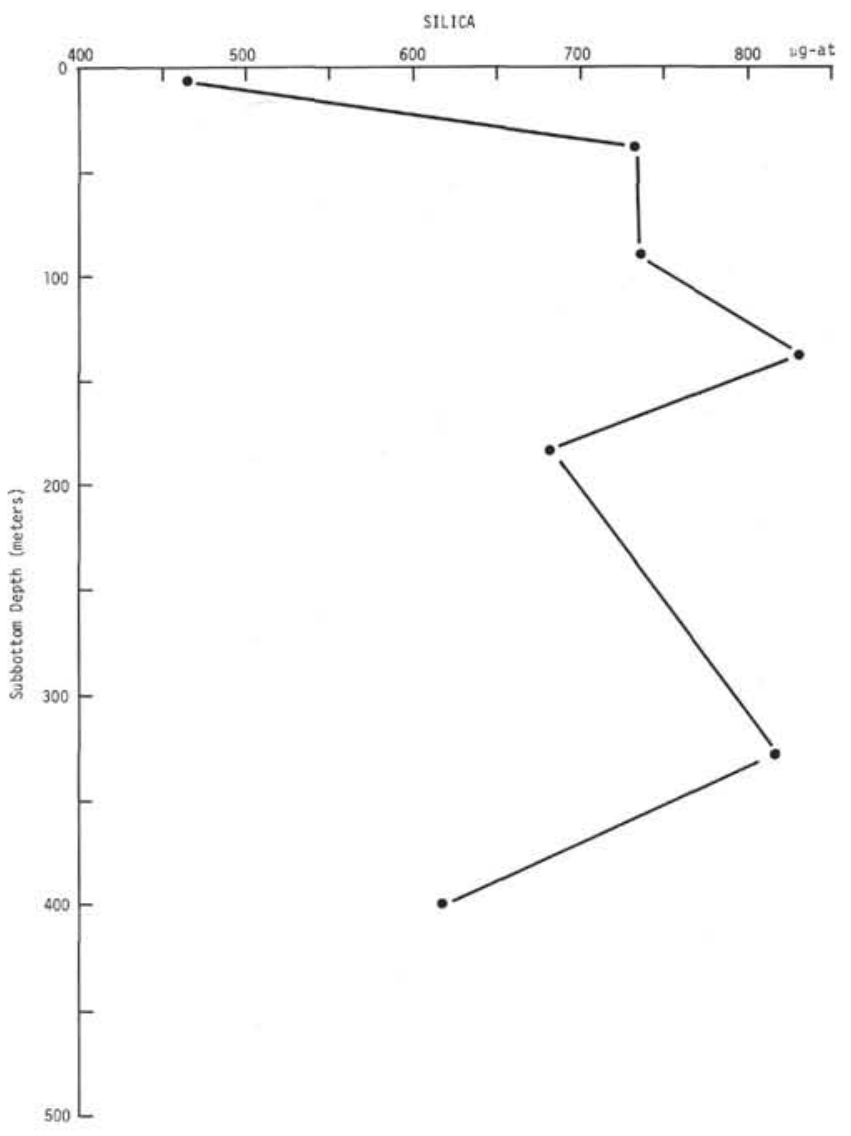

Figure 25. Site 299 - silica. 

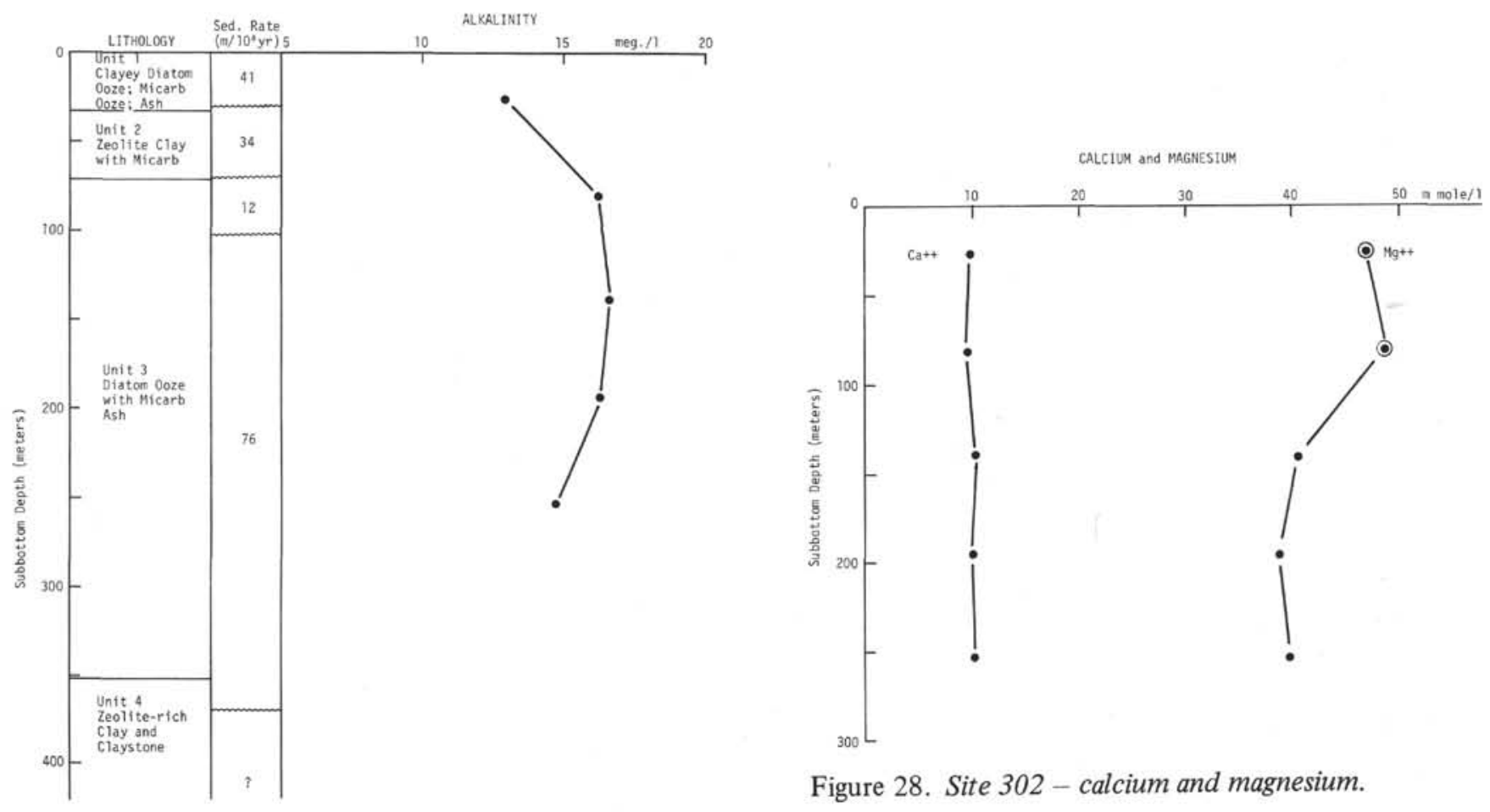

Figure 26. Site 302 - alkalinity.
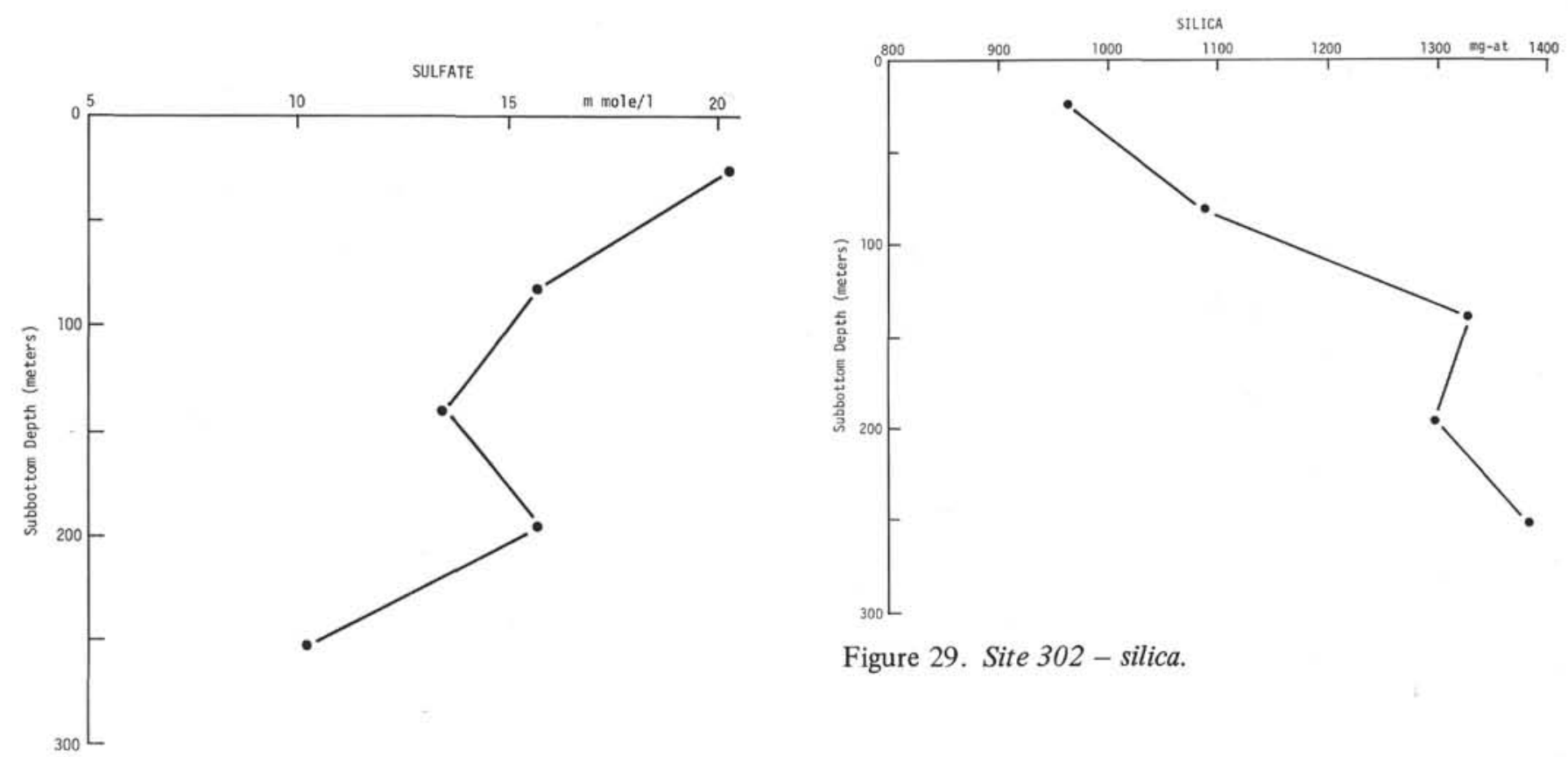

Figure 29. Site 302 - silica.

Figure 27. Site 302 - sulfate. 